\title{
Magnetic nanoparticles in regenerative medicine: what of their fate and impact in stem cells?
}

Aurore Van de Walle ${ }^{\mathrm{a}, *}$, Jose Efrain Perez ${ }^{\mathrm{a}}$, Ali Abou-Hassan ${ }^{\mathrm{b}}$, Miryana Hemadi ${ }^{\mathrm{c}}$, Nathalie Luciani ${ }^{\mathrm{a}}$, Claire Wilhelm ${ }^{\mathrm{a}, *}$

${ }^{\text {a }}$ Laboratoire Matière et Systèmes, Complexes MSC, UMR 7057, CNRS \& University of Paris, 75205, Paris Cedex 13, France

b Sorbonne Université, CNRS UMR 8234, Physicochimie des Electrolytes et Nanosystèmes InterfaciauX (PHENIX), 4 place Jussieu, 75005 Paris, France.

${ }^{\mathrm{c}}$ Interfaces, Traitements, Organisation et Dynamique des Systèmes, Université de Paris, CNRS-UMR 7086, 75205 Paris Cedex 13, France

*Corresponding authors, avandewallep7@gmail.com ; claire.wilhelm@univ-paris-diderot.fr 


\begin{abstract}
With advancing developments over the use of magnetic nanoparticles in biomedical engineering, and more specifically cell-based therapies, the question of their fate and impact once internalized within (stem) cells remains crucial. After highlighting the regenerative medicine applications based on magnetic nanoparticles, this review documents their potential cytotoxicity and, more importantly, underscores their valuable features for stem cell differentiation. It then focuses on the transformations magnetic nanoparticles might experience in cells, mainly consisting in their progressive degradation, and assesses the practical pitfalls related to this degradation. First, it may result in a loss of long-term theranostic potential, and second, it necessitates an adaptation of the cell metabolism to the released iron. Overall, this review demonstrates that magnetic nanoparticles present undeniable interest for stem cell-based biomedical applications; however, each nanoparticle/cell system must be carefully considered for a safe medical use. It also clearly evidences that the biodegradation of the nanoparticles and the cell response to the released iron must be systematically assessed.
\end{abstract}

\title{
Keywords
}

magnetic nanoparticles; iron oxide; nanomedicine; biodegradation; stem cells; iron metabolism. 


\section{Introduction}

Nanotechnology holds the potential to transform the field of medicine by permitting the development of combined and remote theranostic applications. To this effect, multiple nanoparticle configurations have been the subject of intensive research, each of which can be readily interfaced with living cells due to their size compatibility, and each possessing exploitable and unique therapeutic properties [1]. Naturally, over 200 nanotechnology-enabled products have already undergone full clinical trials, and the field keeps expanding. Tailored treatments, such as a patient-specific targeted drug release that minimizes systemic toxicity, have become the current focus of nanoparticle-based therapy.

Within this field of research, magnetic nanoparticles are featured prominently in the development of new diagnostic and therapeutic methodologies, where they pose an exciting prospect due to their inherent properties [2,3]. For instance, their ability to generate a local magnetic field makes them relevant magnetic resonance imaging (MRI) contrast agents [4]. Due to their strong magnetization values, they have been mainly studied as $T_{2}$ contrast agents, but recent efforts have focused on improving their use as $T_{1}$ contrast agents while further increasing $T_{2}$ contrast [5-9]. Magnetic-activated cell sorting (MACS) also uses superparamagnetic nanoparticles with specific targeting antibodies [10] as a standard procedure for the sorting of cell populations, with applications in cancer, stem cell and immunology research, among others [11]. With the advent of microfluidic integration [12-14], magnetic cell sorting has become highly relevant in the field of cancer clinical diagnostics, where it is used and studied for capturing and sorting of circulating tumor cells [15-18]. Magnetic nanoparticles have also been used for cancer therapy via magnetic hyperthermia, or heat generation after exposition to an alternating magnetic field, that is currently under clinical trials for the treatment of prostate carcinoma $[19,20]$ and glioblastoma [21,22]. Recent efforts have focused on the optimization of the heating efficiency by producing new designs [23], such as nanocubes [24] or multicore nanoparticles [25]. Phototermal therapy, a second hyperthermal modality with higher heat generation potential per nanoparticle, has also emerged [26-28].

Recently, the regenerative medicine and tissue engineering fields have found a surge of interest for magnetic nanoparticles, using their magneto-mechanical potential as an innovative approach to spatially organize [29-31] and stimulate [32] stem cells. Magneto-mechanical forces have for example been used for stem cell differentiation into the chondrogenic [33,34], adipogenic [35] or mesodermal cardiac pathways [36]. In most of these applications, the necessary step to endow the cells with the pursued theranostic properties consists in the internalization of magnetic nanoparticles in their intracellular environment. It should be noted first that nanoparticle internalization does not impair the cellular magnetic force generated, being directly the sum of the magnetic moment of each nanoparticle independently of its location, an essential feature in cell targeting, drug delivery and tissue engineering 
applications. What remains to be explored extensively then are the ultimate fate and biotransformations that nanoparticles undergo after cellular uptake and endosomal confinement. Importantly, for most theranostic applications the typically used nanoparticles are iron oxide-based [37], and iron is a naturally occurring bio-element with its own metabolic pathway in mammals. In the organism, it has been described that iron oxide nanoparticles injected intravenously are internalized, mostly in macrophages, then join the iron pool and integrate into the natural iron metabolic pathway. Conversely, the degradation of iron oxide nanoparticles may transform iron oxide into unbound iron ions, which can trigger the generation of reactive oxygen species via the Fenton reaction, leading to oxidative stress and subsequent cell damage [38].

Anti-cancer therapies take advantage of these features by targeting the iron metabolism [39], with the ultimate induction of cell death through ferroptosis [40]. At the opposite, for regenerative medicine applications, any cell damage must be avoided. The relationship between degradation of magnetic nanoparticles and cellular cytotoxicity is not quite clear yet, or at least has not been directly demonstrated. Besides, it is important to highlight that biodegradation of magnetic nanoparticles may not only severely impact their long-term stability, but also decrease their magnetic moment and thus their theranostic potential in the process. Indeed, as shown previously in a stem cell-tissue model, longterm nanoparticle degradation translates into a marked decrease of cell magnetization [41]. Strategies to prevent nanoparticle degradation should then be envisaged to maximize long-term theranostic potential and possibly avoid any source of toxicity. For instance, fine tuning of a gold shell $[42,43]$ or a polymeric coating [44] could shield the nanoparticles from degradation and maintain their integrity and magnetic properties.

Given the upsurge of interest for magnetic nanoparticles in the regenerative medicine field and the challenges imposed by their degradation on their potential cytotoxicity as well as their theranostic applicability, this review will focus on the interplay of these three topics. First, it will summarize the potential of magnetic nanoparticles for regenerative medicine applications, using mostly stem cells as the basis of regeneration, including imaging of stem cell grafts and magnetic stem cell targeting and tissue engineering, among others. Then, discussion will shift to the impact magnetic nanoparticles may have on the differentiation of stem cells, keeping in mind that differentiation processes take weeks and are an indicator of long-term toxicity. Finally, this review will assess a potential correlation between long-term toxicity, intracellular transformations of the nanoparticles, and the alteration in the expression of genes related to iron metabolism. The aim is to draw up the most comprehensive inventory of the reported quantified changes in cellular iron metabolism with time. 


\section{Magnetic nanoparticles for cell-based therapies and regenerative medicine}

Magnetic nanoparticles have a direct applicative potential in biomedicine (Fig. 1). They were first developed as contrast agents for MRI and their range of applications keeps expanding. The number of clinical trials and the increasing amount of products approved by regulatory boards indicate this growing interest. Treatments already at disposition in the clinic include MRI contrast agent for liver lesions (Resovist $₫)$, sentinel node detection $($ Sienna $+\circledR)$, magnetic hyperthermia for brain tumors (Nanotherm®), and treatment of iron deficiency anemia in adults (Feraheme®) [2]. Upon these initial clinical successes, further applications for the regenerative medicine field keep being explored.

\subsection{First generation of applications: Cell tracking}

The first generation of magnetic nanoparticles have been developed for MRI imaging, where they act as contrast agents and can be used for cell delivery with the advantage of tracking (Fig. 1A-C). With this approach, location of the cells can be non-invasively monitored [45]. A pioneer paper looking at cell tracking for the repair of brain injury is from 2002 [46]: the fate of implanted cells was followed for the first time in situ and in vivo, it was a major step toward the assessment of treatment success. Such MRI tracking remains an asset in evaluating current therapies [47-49], especially with the continuous emergence of treatments in regenerative medicine and tissue engineering, as it opens up to opportunities of treatment monitoring for diseases needing stem cell therapy. In the last two decades, the method has been investigated by Bulte et al. for the monitoring of stem cells in conditions including neurological diseases [50-52] and myocardial infarction [53], and by Hoehn et al. [46] and Zhang et al. [54] for the monitoring of stem cells in stroke. More recently, it has been established that mesenchymal stem cells (MSCs) labeled with superparamagnetic iron oxide nanoparticles home to the infarcted myocardium and can be detected by MRI up to three weeks post-injection into the ischemic area of rats [55]. In pig models, Ferumoxytol® has also proven to be a reliable labeling method to track cardiac progenitor cells derived from embryonic stem cells for up to 40 days [56]. Magnetically-labeled neural stem cells have also been successfully transplanted into mice striatum and differentiated into neurons and astrocytes, as observed by MRI [57]. Similarly, adipose-derived stem cells labeled with iron oxide nanoparticles can be tracked in vivo for up to five weeks, showing promise in the treatment of osteoarthritis [58]. Magnetic particle imaging (MPI) emerged in 2005 as an alternative imaging technique, pioneered by Bernhard Gleich and Jürgen Weizenecker from the Philips Research Laboratories of Hamburg [59]. This technique images superparamagnetic iron oxides tracers by directly measuring their response to magnetic fields using relaxometry. MPI provides high resolution spatial and temporal distribution of 
tracers and has the advantage of presenting no background noise as the human body does not typically hold magnetic interference. Using MPI, the tracking and monitoring of implanted neural cell grafts in the brain of rats has for example been achieved over three months [60].

\subsection{Second generation of applications: Magnetic cell manipulation}

Magnetic nanoparticles obey the Coulomb's law and can be manipulated at a distance by an external magnetic field gradient. The intrinsic penetrability of magnetic fields into human tissues, combined with the possibility of acting on these nanoparticles at a distance leads to applications involving the transport and/or immobilization of cells. These properties are being used to direct cells toward specific sites, create tissues, and control cell function.

\subsubsection{For cell delivery to specific organs}

A challenge in cell-based therapies is to direct and retain stem cells or engineered cells at the site of damage. Developing new ways of delivering cells to diseased tissues will be a key factor in translating cell therapeutics research into clinical use. In this context, magnetic targeting has emerged as a new strategy to aid delivery, increase retention, and enhance the effects of stem cells for a long-lasting and effective therapy. It has been shown in vitro with pre-programmed magnetic micro-'hot spots' [61] or fluid flow models [62] and in vivo [63,64] that cell migration can be directed at the microscale level using magnetic nanoparticles (Fig. 1C). A first demonstration of cell delivery feasibility in vivo was performed with rat MSCs that were labeled and targeted magnetically by applying an external magnetic field to the upper hemisphere of a rodent retina [65]. Such methodology allowed cell migration through the blood stream to the targeted brain area. Magnetic targeting has since been applied to a number of areas (in small rodents mostly) such as the brain [66], the spinal cord [67-69], bones [70,71], articular cartilage [72,73], and skeletal muscle [74,75]. Initial clinical translation has been performed for the repair of articular cartilage defects in five patients [76] by injecting magnetically labeled MSCs into the knee joint and attracting cells to the surface of the lesion using a compact magnet attached to a suitable position around the knee joint for $10 \mathrm{~min}$. The efficacy of the targeting was confirmed by MRI with a complete coverage of the defect and significant improvement in clinical outcomes was observed 48 weeks after treatment. 


\subsubsection{For $3 \mathrm{D}$ tissue assembly}

The field of tissue engineering is attracting increased attention mostly due to the lack of clinically relevant implants and organs for surgical repair of defects. A challenge in the field is the specific manipulation of cells to both create organized tissues and drive their appropriate functionalization. Magnetic nanoparticles have proven their use to facilitate these processes [77,78]. They have been used to create localized cell layers (e.g. attract endothelial cells on the lumenal surface of blood vessel $[79,80]$ ), organize a vascular network [81], create cell-sheets [82,83], and develop tissues (e.g. cartilage [34], bone [82,84], skeletal muscle [83]). They allow the manipulation of independent cells up to forming cell spheroids that can be assembled magnetically in cm-large (macro-scale) tissues, leading to the development of scaffold-free replacements [33,85-87]. These tissue blocks can be engineered by various techniques, including seeding on top of permanent micromagnets or magnetic levitation (Fig. 1D). For the magnetic levitation, an external magnetic field levitates and concentrates cells suspended in medium at the air-liquid interface, where they aggregate to form larger $3 \mathrm{D}$ cultures $[88,89]$. These approaches allow for control of cell mass geometry and guided, multicellular clustering of different cell types in co-culture through spatial variance of the magnetic field [90]. More complex tissue structures can be assembled this way more easily than with more conventional scaffold-based tissue engineering strategies: scaffold-free cellular rings or sheets can for example be produced (Fig. 1E-F). Organized cellular assembly with multiple cell types can also be facilitated. Additionally, magnetic approaches allow guiding cells within thick scaffolds: for instance magnetically labeled stem cells have been compacted within a thick matrix, allowing for better differentiation down the chondrocyte lineage $[34,85]$.

\subsubsection{To control cell function}

In addition to being a tool for tissue development, magnetic nanoparticles have been applied to intracellular and extracellular signal control of cells [91]. Cell functions are mainly modulated by growth and bioactive factors that bind to membrane receptors; however, mechanotransduction pathways responding to mechanical stresses can also influence and control cellular behaviors [92] and have beneficial effects on stem cell differentiation and tissue formation [93,94]. Over the more classical bioreactor approach to generate mechanical forces, magnetic force-based methodologies have the advantages of remote control with spatial and/or temporal precision. Upon nanoparticles internalization in cellulo, localized nanoparticle-mediated forces can be applied and trigger signal transduction pathways leading to cellular response [95,96]; they can for example be used to apply forces (tensile or compressive) on stem cells, drive their differentiation [36] and improve their therapeutic potential [97] (Fig. 1G). Functionalized nanoparticles can also be used to activate specific cell surface 
mechanoreceptors and initiate their signaling response [98,99] (Fig. 1H). Magnetic nanoparticletriggered aggregation of specific receptors has also been shown to be able to trigger $\mathrm{T}$ cell activation and the subsequent inhibition of melanoma [100], as well as the inhibition of apoptosis in vitro and in vivo when conjugated to a cell death targeting antibody [101]. Other works have also focused on the effects of mechanical stimulation triggered by magnetic nanoparticles in neurons, where it can promote cell growth by targeting signaling endosomes [102], trigger calcium influx through mechano-sensitive ion channels [103] and induce cell displacement by altering the cytoskeleton [104]. Lastly, the delivery of genetic materials into stem cells in a highly efficient and controlled manner could also be facilitated using magnetic nanoparticles complexed with siRNA or pDNA [37].

Magnetic hyperthermia with nanoparticles, typically a cancer treatment therapy, has in recent years found a new use as a cell function regulator. It can, for instance, target and locally activate specific temperature-sensitive (TRPV1) cation channels, triggering an action potential in neurons [105-107] or the release of bioengineered insulin in mice tumors [108]. After application of a magnetic hyperthermia treatment, surviving bone cancer cells showed an increased expression of alkaline phosphatase (ALP), an early marker of osteogenesis, demonstrating the potential of such a thermal effect in inducing differentiation [109]. 

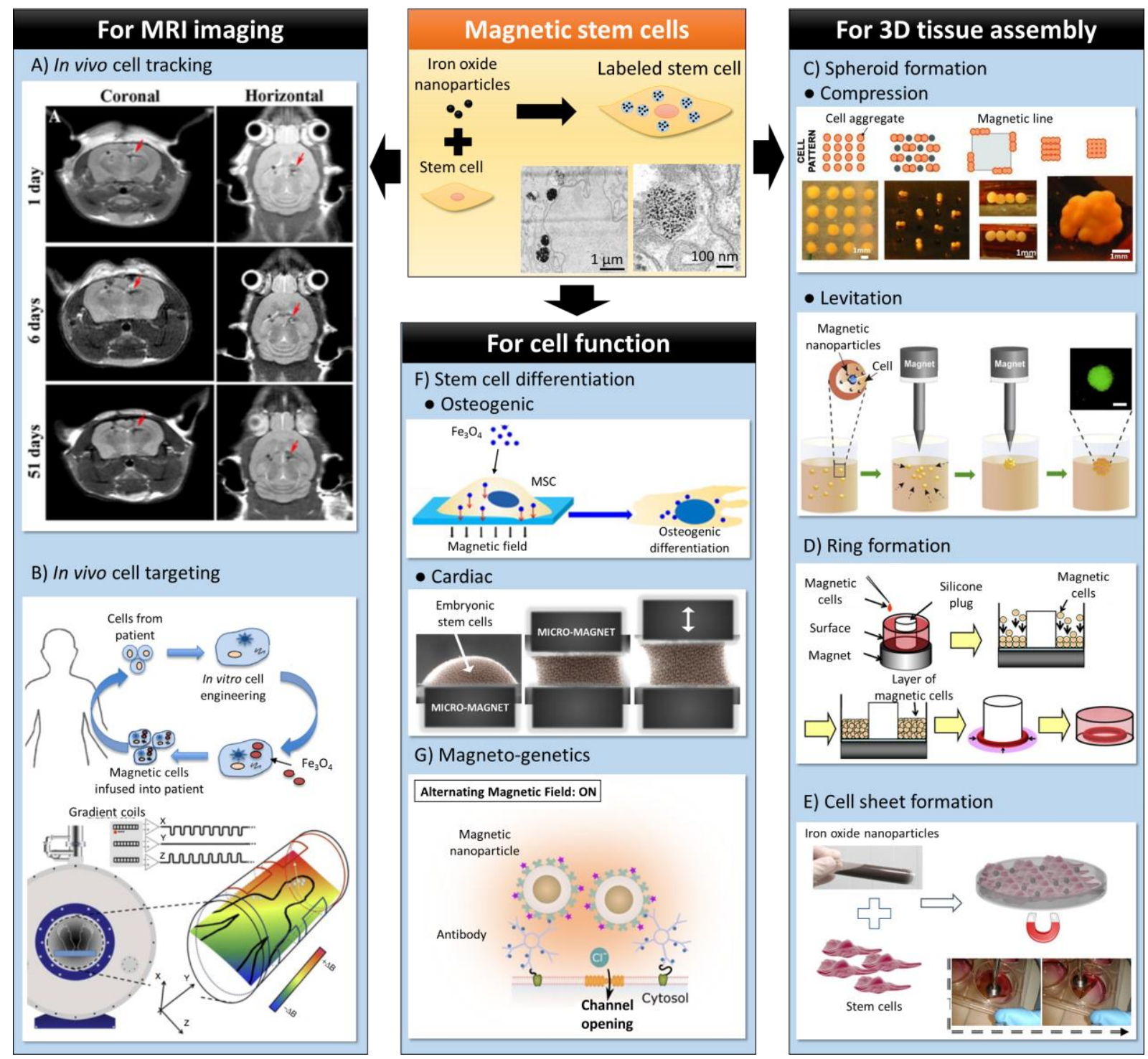

Fig. 1: Applicative potential of magnetic nanoparticles in biomedical engineering. Labeling of stem cells with magnetic nanoparticles is a promising tool in regenerative medicine, for applications such as cell tracking by means of MRI, direction of cell function or for the creation of tissues. A-B) Labeled cells can be tracked by MRI, which allows cell monitoring in vivo (A, extracted and modified from [57]). Magnetic resonance can also be used to target cells at a given site in vivo (B, extracted and modified from [110]). C-E) Tissues can be developed by guiding cells magnetically. Stem cells can this way be aggregated as spheroids either by magnetic compression or levitation at the fluid interface with air $(\mathrm{C}$, extracted and modified from [33] and [111]). Other tissue shapes such as rings (D, extracted and modified from [83]) or cell sheets (E, extracted and modified from [112]) have also been developed. FG) Cell function can be modulated at a distance by applying forces magnetically that induce stem cell differentiation toward responding pathways, such as osteogenic differentiation with compression or cardiac with tensile forces (F, extracted and modified from [113] and [36]). G) Signaling pathways can be triggered magnetically, including those that induce stem cell differentiation (extracted and modified from [114]). 


\section{Impact of magnetic nanoparticles on stem cells}

\subsection{Synthesis of magnetic nanoparticles}

Numerous chemical methods can be used to synthesize magnetic nanoparticles: coprecipitation of iron salts [115-118], sol-gel synthesis [119] including microwave assisted ones[120], hydrothermal reactions [121], hydrolysis and thermolysis of precursors [122], synthesis in microemulsions [123], flow injection synthesis [124], electrospray synthesis [125] and microfluidic flow synthesis [126-130]. In the frame of this review we will only cover very briefly the main bottom-up chemical preparation routes in bulk, which paved the way to the field of biomedical applications such as cell-based therapies.

The coprecipitation method is one of the most popular reported methods in the literature for the preparation of magnetic nanoparticles [131]. It is a facile and a convenient way to synthesize biocompatible iron oxides (either $\mathrm{Fe}_{3} \mathrm{O}_{4}$ or $\gamma-\mathrm{Fe}_{2} \mathrm{O}_{3}$ ) in water from a stoechiometric aqueous $\mathrm{Fe}^{2+} / \mathrm{Fe}^{3+}$ salt solutions by addition of a base under inert atmosphere at room temperature or elevated temperature. The first controlled preparation of superparamagnetic iron oxide particles was performed by Massart in the $1980^{\text {th }}$ by alkalinisation of an aqueous mixture of $\mathrm{FeCl}_{3}$ and $\mathrm{FeCl}_{2}$ salts [132]. By modulating the synthesis parameters ( $\mathrm{pH}$, iron ratio, ionic strength, etc), magnetic nanoparticles with a rock-like shape morphology and a mean diameter ranging between 4 to $16 \mathrm{~nm}$ can be prepared with a good reproducibility [115]. By varying the reaction conditions, the size can be increased to up to $40 \mathrm{~nm}$. In addition to the biocompatibility of the nanoparticles, they are synthesized at a large scale, allowing their easy and fast translation to any application including in the biomedical field. To decrease the polydispersity of the obtained nanoparticles, size sorting can be used to achieve by this process a narrow particle size distribution. Moreover, the synthesized particles are obtained without any surfactant. Consequently they can be coated by a wide range of molecular species such as amino acids, $\alpha$ hydroxyacids (citric, tartric, and gluconic acids)[133], hydroxamate (arginine hydroxamate) [134], dimercaptosuccinicacid (DMSA)[135,136], or phosphoryl choline [137], polyelectrolytes and polymers including poly-(ethylene glycol) chains to increase their resistance to biological environnements [138]. Co-precipitation is also used for the preparation of ferrites, by replacing a part of the $\mathrm{Fe}^{2+}$ by another divalent cation such as $\mathrm{Sr}^{2+}, \mathrm{Ba}^{2+}, \mathrm{Zn}^{2+}, \mathrm{Ni}^{2+}, \mathrm{Co}^{2+}, \mathrm{Mn}^{2+}$ in the starting solutions. Since maghemite $\left(\mathrm{Fe}_{2} \mathrm{O}_{3}\right)$ shows less toxic effects than magnetite or other divalent ferrites, maghemite nanoparticles find increasing application for medical purposes [139].

Decomposition of organometallic compounds in high-boiling organic solvents containing stabilizing surfactants is a procedure that has also been widely used to produce magnetic nanoparticles. In this protocol the nanoparticles are obtained with high level of monodispersity and crystallinity. The size and morphology of the nanoparticles can be controlled by adjusting the reaction times, as well as the aging 
period, the temperature, the concentration and ratios of the reactants, the nature of the solvent, of the precursors, and the addition of seeds. Shapes such as nanocubes can be also prepared by the thermal decomposition method [140]. These high-quality synthesized nanoparticles are initially dispersed in organic solvents, and post preparative methods are required to make them water-soluble.

Another promising method for the synthesis of uniform and water-soluble nanoparticles that could be used in biomedical applications is the polyol technique. In this process, owing to their high dielectric constants, polyols (for example ethylene glycol, diethylene glycol) are used as solvents to dissolve inorganic compounds. They also play the role of reducing agents, and of stabilizers, allowing to control the particles growth and prevent interparticle aggregation [141]. Moreover, thanks to their relatively high boiling points, they also offer a wide range of operating temperatures for producing inorganic compounds [142]. This chemical approach has been described for the preparation of well-defined shapes (spheres, clusters, raspberry, multicore flowers) and controlled sizes (5 -50 nm) of oxides nano- and microparticles [8,143-153]. The resulting nanoparticles in the polyol process are highly crystalline with a high magnetic saturation. Moreover, they can be easily dispersed in aqueous media and other polar solvents because their surface contains many hydrophilic ligands. The surface can also be modified with different ligands such as citrate after several washing steps to eliminate the excess of polyols.

By comparing the three processes, the co-precipitation method remains the easiest and the most reliable to implement in a laboratory at a large scale, in addition to being the most economical and green compared to the others. No special precursors, high boiling solvents, temperature gradients control or multi- post-preparative steps are required at the end of the synthesis. A large amount of biocompatible magnetic nanoparticles can be produced and their surface modified on demand with different ligands to fulfill the desired requirements.

\subsection{Do magnetic nanoparticles affect cellular functions?}

Assessing the toxicity of magnetic nanoparticles and their further impact on cellular function is a requirement for their safe establishment in the clinic. This has been largely explored in the community, with numerous studies specifically devoted to toxicological analyses. What has in some cases been reported (mostly in vitro) are negative effects of the nanoparticles at the molecular and cellular levels, i.e. altered actin cytoskeleton, affected focal adhesion-mediated cell signaling pathways, reduced cell motility, transformed cell cycles and disruption of the cell membrane, among others, which can result in diminished cell viability [154-157]. Genotoxic effects have also been described with DNA damage, chromosome aberrations, and production of micronucleus all having been observed [158]. From these results, the use of magnetic nanoparticles in the clinic can seem irrelevant and unsafe; however, 
contradictory data are even more frequent, with a large number of studies reporting no adverse effect neither on stem cells nor on other typical cell lines [158-160].

It has also become apparent that in vitro models, despite being crucial for comprehensive and quantitative assessment, do not represent the full complexity of the organism. In vivo studies that involve uptake and distribution of the nanoparticles in the body are necessary as they consider another level of complexity. Indeed, in vivo the nanoparticles are in contact with biological fluids and, immediately after injection, they interact with the plasma proteins (opsonins) which results in the adsorption of these proteins on their surface. This process, named opsonization, will take place at different rates depending on the nanoparticle features, particularly its coating nature [161,162]. Toxicology results obtained in vivo in diverse animal models (e.g. rats, mice, chickens, monkeys, dogs) have also showed controversial results. They demonstrated a dose-dependent effect of magnetic nanoparticles, with, at higher doses, increased micronucleus occurrence, increased DNA breaks, weakened inflammatory reaction, though no adverse effects were frequently observed $[158,163]$.

What has been deduced from all these studies is that biosafety depends on an interplay of factors influencing the interactions between nanoparticles and cellular components. Among them, the structure of the nanoparticles needs to be carefully considered and several parameters have been specifically assessed: their shape, size, and coating $[164,165]$. The shape strongly influences the physiochemical properties of the nanoparticles but the various geometries do not seem to have an impact on toxicity [165]. Second, the size has been determined to play a role in cellular internalization and clearance. In vivo, large nanoparticles (> $100 \mathrm{~nm}$ ) will for example be quickly removed from the blood stream by the spleen and liver $[166,167]$. In vitro, size has also been linked to varying internalization rate and was shown to have an impact on biocompatibility, with for example an increase in size from 4 to $8 \mathrm{~nm}$ leading to increased internalization as well as increased biocompatibility when comparing a same internalized dose [168]. Finally, the coating, anchored at the surface of the nanoparticle, impacts both the inter-nanoparticle interactions and the interactions with the biological environment [169]. The first function of the coating is to prevent clustering of nanoparticles prior to cell internalization. Coating is also responsible for the surface charge of the nanoparticles, with charged coatings known to promote interaction with cells in contrast to neutral ones [170,171].

To conclude, the structure of magnetic nanoparticles (i.e. size, shape, and coating) directly influences their internalization, meaning the "dose" of nanoparticles in the cell. This dose also depends on cell type variations $[159,168]$ and, naturally, on the incubation concentration as well as time of exposure. It seems to be the main factor of toxicity with a clear dose-dependent response of the cells [163,172-174].

Importantly, positive toxicology assessments have led to the acceptance of magnetic nanoparticles in the clinic. For now, the use of magnetic nanoparticles in clinical imaging has been stopped, mainly 
because the negative MRI signal was not specific enough for the radiologist to lead to clinical assessments. However, information regarding the possible risks associated with their exposure to humans is still limited and conflicting. It has to be noted that clinical applications have mostly been limited to dextran coated nanoparticles (e.g. Ferumoxide, Ferumoxytol, Ferucarbotran) by IV injection and silica coated (Ferumoxsil) by oral administration [2]. Adverse effects have sometimes been demonstrated and linked to the labile iron, while hypersensitivity reactions were attributed to the coating [175]. Precise specifications that describe the ideal non-toxic magnetic nanoparticle are still missing and, as of today, each nanoparticle-cell system should be carefully evaluated independently to avoid any adverse effect. Importantly as well, in depth analyses of the nanoparticles' fate once within the cells is necessary for full comprehension and optimization of the nanoparticles for the clinic.

\subsection{From potential toxicity to enhanced functionality}

Most of the toxicological studies performed in vitro have focused on immediate effects of nanoparticles on cells upon exposure. For a thorough assessment, systematic and quantitative studies of the long-term nanoparticle bio-kinetics in the biological environment are needed. As a high number of cell-based therapies are based on stem cells, performing long-term investigations on stem cells is not only pertinent but also required, and must be correlated to their differentiation potential.

The internalization of nanoparticles in stem cells not only depends on their characteristics (e.g. coating, size, shape) $[164,165,176]$ but also on the features of the cells (e.g. type, donor, status) $[159,168,177,178]$, both relevant when considering cellular toxicity. For a same setting (i.e. identical nanoparticles and cell model), the internalization dose has been identified as a main determinant of toxicity [163,172-174]. Herein, we will first focus on the negative impact of a high dose of magnetic nanoparticles on stem cell functionality. We will then focus on their positive effects when at a lower and non-toxic dose, either by their presence alone or when used to trigger a mechanotransduction signal. 


\subsubsection{High dose of internalized nanoparticles can have deleterious effects}

Under high dosage of internalized nanoparticles, the differentiation potential of stem cells has been shown as affected [173,179-182]. These effects seem to be specific to the differentiation pathway, with a same high dose inhibiting chondrogenesis but not osteogenesis nor adipogenesis [53,177,183-186]. We for example observed that, using citrate-coated maghemite nanoparticles ( $8 \mathrm{~nm}$ core), the differentiation of MSCs into chondrocytes, adipocytes or osteocytes was similar to that of unlabeled cells when less than $10 \mathrm{pg}_{\mathrm{Fe}} /$ cell were internalized; however, when 30 to $60 \mathrm{pg}_{\mathrm{Fe}} /$ cell were internalized the chondrogenesis was negatively impacted, but not the adipogenesis nor the osteogenesis $[177,184]$. Andreas et al. observed that MSCs incubated with citrate-coated magnetic nanoparticles and commercial Endorem (ferumoxide) presented no alterations in chondrogenic capacity when at less than $15 \mathrm{pg}_{\mathrm{Fe}} / \mathrm{cell}$ for the citrated nanoparticles and less than $5 \mathrm{pg}_{\mathrm{Fe}} /$ cell for the ferumoxides [185]. However, when the dose was above $30 \mathrm{pg}_{\mathrm{Fe}} /$ cell for the citrate nanoparticles and $26 \mathrm{pg}_{\mathrm{Fe}} /$ cell for the ferumoxides this capacity was impacted as denoted by a clear inhibition of chondrogenesis. Here again, adipogenesis and osteogenesis were not inhibited even at high doses of $70 \mathrm{pg}_{\mathrm{Fe}} /$ cell of citrated nanoparticles and 26 $\mathrm{pg}_{\mathrm{Fe}} / \mathrm{cell}$ of ferumoxides [185]. The threshold dose above which negative events are observed varies depending on the differentiation pathway and also on the nanoparticles. Table 1 provides this intracellular dose, when available, for different studies, and correlates it with the potential impact. Overall, no adverse events are observed for less than $10 \mathrm{pg}$ of iron per cell, which can thus be considered as the low dose threshold.

The high dose toxicity could be linked to nanoparticle interference with intracellular signaling processes [183], or to a modification of the cellular morphology with higher nuclear to cytoplasmic ratio, detrimental for chondrogenic differentiation [187]. Finally, when at a high dose and not provoking adverse events, it was observed that magnetic nanoparticles increased the proliferation of stem cells [179].

\subsubsection{Positive differentiation driven by magnetic nanoparticles without external stimulation}

Long-term (days to months) studies assessing differentiation have shown that magnetically labeled stem cells keep their differentiation potential as chondrocytes, adipocytes, osteocytes, myocytes, and neuronlike cells (Table 1). In most these studies, a first assessment consists in setting up adequate culture parameters such as incubation concentration and time which results in an internalization dose presenting no negative impact on the cells. Under specific differentiation pathways, this low dose can even improve differentiation. Such a phenomenon has been demonstrated for adipogenesis and osteogenesis [188- 
190]. Under adipogenesis, the deposition of lipid vacuoles was shown to increase [188]. Under osteogenesis, calcium deposits and ALP activity were enhanced, as well as the expression of typical osteogenic genes and proteins such as RunX2 and BMP2 [188-190]. A detailed mechanism has been described for the osteogenesis, with magnetic nanoparticles activating the mitogen-activated protein kinase (MAPK) signal pathway and upregulating INZEB2, which is critically important to maintain osteogenesis [190,191].

Table 1: Negative, positive or neutral impact of magnetic nanoparticles on the differentiation of stem cells depending on the nanoparticles' features, the internalized dose, and the labeling protocol. Nanoparticles $(\mathrm{NP})$, hydrodynamic diameter $\left(\mathrm{D}_{\mathrm{h}}\right.$, determined by dynamic light scattering), core size diameter ( $\mathrm{D}_{\mathrm{c}}$, determined by transmission electron microscopy), concentration (conc.), references (ref.), amine($\mathrm{NH}^{3+}$ ), dimercaptosuccinic acid (DMSA), amino-polyvinyl alcohol (A-PVA), poly(acrylic acid) (PAA), polyglucose sorbitol carboxymethyl-ether (PSC), human MSC (hMSC), mouse MSC (mMSC), rat MSC (rMSC), ovine and equine mesenchymal stem cells (o\&eMSCs), human embryonic stem cells (hESCs), mouse embryonic stem cells (mESCs)

\begin{tabular}{|c|c|c|c|c|c|c|c|c|c|c|}
\hline $\begin{array}{l}\text { Diff. } \\
\text { pathway }\end{array}$ & Impact & $\begin{array}{l}\text { NP composition } \\
\text { (core/coating) }\end{array}$ & Cell type & $\begin{array}{l}\text { NP Dh } \\
(\mathrm{nm})\end{array}$ & $\begin{array}{l}\text { NP } D_{c} \\
(\mathrm{~nm})\end{array}$ & $\begin{array}{l}\text { NP conc. } \\
(\mu \mathrm{g} / \mathrm{mL})\end{array}$ & $\begin{array}{l}\text { Incubation } \\
\text { time }\end{array}$ & $\begin{array}{l}\text { Iron / } \\
\text { cell (pg) }\end{array}$ & $\begin{array}{l}\text { Experiment } \\
\text { time (days) }\end{array}$ & Ref. \\
\hline \multirow[t]{16}{*}{ Adipo } & Negative & Magnetite/- $\mathrm{NH}^{3+}$ & hMSCs & - & 6 & 50 & $24 \mathrm{~h}$ & $550-2000$ & 21 & [179] \\
\hline & Neutral & Ferumoxide & hMSCs & 157 & 4.5 & 500 & $24 \mathrm{~h}$ & 26 & - & {$[185]$} \\
\hline & & & hMSCs & - & - & 6 & $24 \mathrm{~h}$ & - & 13 & [192] \\
\hline & & & mMSCs & $80-150$ & - & 348 & $24 \mathrm{~h}$ & 6 & 21 & [193] \\
\hline & & & hMSCs & - & - & 25 & $24 \mathrm{~h}$ & - & 20 & {$[53,183]$} \\
\hline & & & o\&eMSCs & - & - & 25 & $12 \mathrm{~h}$ & - & 21 & [186] \\
\hline & & & rMSCs & - & - & $50 \& 100$ & $48 \mathrm{~h}$ & - & 12 & [194] \\
\hline & & Ferumoxtran-10 & mMSCs & $20-40$ & - & 500 & $24 \mathrm{~h}$ & $\sim 3$ & 21 & [193] \\
\hline & & Ferucarbotran & mMSCs & 60 & - & 50 & $24 \mathrm{~h}$ & $\leq 15$ & 21 & [193] \\
\hline & & & o\&eMSCs & - & - & 933 & $24 \mathrm{~h}$ & - & 21 & [186] \\
\hline & & Maghemite/DMSA & hMSCs & - & $5-18$ & 80 & $24 \mathrm{~h}$ & 17 & 24 & [195] \\
\hline & & Maghemite/A-PVA & hMSCs & 42 & 7 & $50-400$ & $4 \& 24 \mathrm{~h}$ & $6-11$ & 14 & [196] \\
\hline & & Maghemite/citrate & hMSCs & 20 & 8 & $5-28$ & $0.5 \& 4 \mathrm{~h}$ & $3-60$ & 21 & {$[177,184]$} \\
\hline & & Magnetite & rMSCs & - & - & 20 & $12 \mathrm{~h}$ & 18 & - & [197] \\
\hline & & Iron oxide/citrate & hMSCs & 98 & $6-7$ & 25 & $24 \mathrm{~h}$ & 70 & - & [185] \\
\hline & Positive & Magnetite/ PAA & hMSCs & 33 & - & $29-115$ & $30 \mathrm{~min}$ & - & 16 & [188] \\
\hline \multirow[t]{19}{*}{ Osteo } & Negative & Ferumoxide & hMSCs & - & - & 6 & $24 \mathrm{~h}$ & - & 13 & [192] \\
\hline & & Ferucarbotran & hMSCs & 62 & - & $30-300$ & $1 \mathrm{~h}$ & $61-68$ & 7 & [180] \\
\hline & & Magnetite/- $\mathrm{NH}^{3+}$ & hMSCs & - & 6 & 50 & $24 \mathrm{~h}$ & $550-2000$ & 21 & [179] \\
\hline & Neutral & Ferumoxide & hMSCs & 157 & 4.5 & 500 & $24 \mathrm{~h}$ & 26 & - & [185] \\
\hline & & & mMSCs & $80-150$ & - & 348 & $24 \mathrm{~h}$ & $\sim 6$ & 21 & [193] \\
\hline & & & hMSCs & - & - & 25 & $24 \mathrm{~h}$ & - & 17 & {$[53,183]$} \\
\hline & & & o\&eMSCs & - & - & 25 & $12 \mathrm{~h}$ & - & 21 & [186] \\
\hline & & & rMSCs & - & - & $50 \& 100$ & $48 \mathrm{~h}$ & - & 28 & [194] \\
\hline & & Ferumoxtran-10 & mMSCs & $20-40$ & - & 500 & $24 \mathrm{~h}$ & $\sim 3$ & 21 & [193] \\
\hline & & Ferucarbotran & mMSCs & 60 & - & 50 & $24 \mathrm{~h}$ & $\leq 15$ & 21 & [193] \\
\hline & & & o\&eMSCs & - & - & 933 & $24 \mathrm{~h}$ & - & 21 & [186] \\
\hline & & Maghemite/DMSA & hMSCs & - & $5-18$ & 80 & $24 \mathrm{~h}$ & 17 & 24 & [195] \\
\hline & & Maghemite/A-PVA & hMSCs & 42 & 7 & $50-400$ & $4 \& 24 h$ & $6-11$ & 13 & [196] \\
\hline & & Maghemite/citrate & hMSCs & 20 & 8 & $5-28$ & $0.5 \& 4 \mathrm{~h}$ & $3-60$ & 21 & {$[177,184]$} \\
\hline & & Magnetite & rMSCs & - & - & 20 & $12 \mathrm{~h}$ & 18 & - & [197] \\
\hline & & Magnetite/BSA & rMSCs & $150-200$ & - & 50 & $24 \mathrm{~h}$ & - & 21 & [113] \\
\hline & & Iron oxide/citrate & hMSCs & 98 & $6-7$ & 25 & $24 \mathrm{~h}$ & 70 & - & [185] \\
\hline & Positive & Maghemite/PSC & hMSCs & 30 & $7-8$ & $10-300$ & continuous & - & 21 & {$[190,191]$} \\
\hline & & Magnetite/PAA & hMSCs & 33 & - & $29-115$ & $30 \mathrm{~min}$ & - & 21 & [188] \\
\hline
\end{tabular}




\begin{tabular}{|c|c|c|c|c|c|c|c|c|c|c|}
\hline \multirow[t]{17}{*}{ Chondro } & Negative & Ferumoxide & hMSCs & 157 & 4.5 & 500 & $24 \mathrm{~h}$ & 26 & 28 & [185] \\
\hline & & & hMSCs & - & - & 25 & $24 \mathrm{~h}$ & - & 21 & {$[53,183]$} \\
\hline & & & hMSCs & - & - & $12-1600$ & $24 \mathrm{~h}$ & - & 28 & [182] \\
\hline & & Ferucarbotran & hMSCs & 62 & 11 & 28 & $24 \mathrm{~h}$ & - & 14 & [198] \\
\hline & & & hMSCs & 62 & - & 100 & $4 \& 18 \mathrm{~h}$ & $3-26$ & 14 & [187] \\
\hline & & & o\&eMSCs & - & - & 933 & $24 \mathrm{~h}$ & - & 21 & [186] \\
\hline & & Maghemite/citrate & hMSCs & 20 & 8 & $11-45$ & $0.5 \& 4 \mathrm{~h}$ & $>30$ & $21-28$ & {$[173,177,184]$} \\
\hline & & Magnetite/-NH ${ }^{3+}$ & hMSCs & - & 6 & 50 & $24 \mathrm{~h}$ & $550-2000$ & 21 & [179] \\
\hline & & Iron oxide/citrate & hMSCs & 98 & $6-7$ & $\geq 10$ & $24 \mathrm{~h}$ & $\geq 30$ & 28 & [185] \\
\hline & Neutral & Ferumoxide & hMSCs, & 157 & 4.5 & $<100$ & $24 \mathrm{~h}$ & $<13$ & 28 & {$[185]$} \\
\hline & & & hMSCs & - & - & $\sim 6$ & $24 \mathrm{~h}$ & - & 13 & [192] \\
\hline & & & hMSCs & $80-150$ & - & 50 & overnight & - & 20 & [199] \\
\hline & & & o\&eMSCs & - & - & 25 & $12 \mathrm{~h}$ & - & 21 & [186] \\
\hline & & Ferucarbotran & hMSCs & - & - & $1-100$ & $24 \mathrm{~h}$ & - & 30 & [200] \\
\hline & & Maghemite/A-PVA & hMSCs & 42 & 7 & $50-400$ & $4 \& 24 \mathrm{~h}$ & $6-11$ & 21 & [196] \\
\hline & & Maghemite/citrate & hMSCs & 20 & 8 & $5-28$ & $30 \mathrm{~min}$ & $\leq 10$ & $21-28$ & {$[173,177,184]$} \\
\hline & & Iron oxide/citrate & hMSCs & 98 & $6-7$ & 1 & $24 \mathrm{~h}$ & $<15$ & 28 & [185] \\
\hline Myogenic & Neutral & Ferumoxide & rMSCs & - & - & $50 \& 100$ & $48 \mathrm{~h}$ & - & 28 & [194] \\
\hline \multirow{2}{*}{$\begin{array}{l}\text { Neuron- } \\
\text { like }\end{array}$} & Negative & Ferucarbotran & hMSCs & - & - & 28 & continuous & - & 7 & [172] \\
\hline & Neutral & Ferucarbotran & hMSCs & - & - & $\leq 14$ & continuous & - & 7 & [172] \\
\hline \multirow[t]{2}{*}{ Cardiac } & Neutral & Ferumoxytol & hESCs & - & - & $50-300$ & $24 \mathrm{~h}$ & - & 10 & [56] \\
\hline & & Iron oxide & mESCs & - & - & 50 & $24 \mathrm{~h}$ & - & 18 & [201] \\
\hline
\end{tabular}

\subsubsection{Improved differentiation driven by magnetic-mediated stimuli}

Remote magnetic stimulation enabled by the magnetic labeling of stem cells can induce specific differentiation (Table 2). A direct application consists in driving magnetically the compaction of cells as cell-cell contact is crucial for triggering some differentiation pathways, including chondrogenesis. It was demonstrated that confining stem cells into a thick scaffold or driving aggregate formation using magnetic stem cells and remote magnets were sufficient to impose the cell compaction needed for the chondrogenic differentiation, as demonstrated by increased collagen II and aggrecan gene expressions $[34,85]$.

Beyond promoting cell-cell contact, magnetic forces can also be used to stimulate stem cells in their tissue environment, in a form of magneto-mechanical stimulation. Indeed, it is established that external mechanical forces regulate stem cell differentiation and play a major role in embryogenesis and in maintaining cell function. Most studies assessing the effects of biomechanical stimulation are performed via direct contact to the cells; using magnetic nanoparticles combined with a magnetic field is an innovative approach that allows the mechanical stimulation of stem cells at a distance. In this case, a magnet is used that has either a static role of permanent cell compression or a dynamic role of oscillatory stimulation by cycling at a given frequency (Table 2). A dynamic magnetic field has the advantage of being more representative of the loading forces sensed by the cells. We can then distinguish two types of stimuli: compressive or tensile. Compressive magnetic stimulation has been mostly explored for chondrogenesis and osteogenesis while tensile magnetic stimulation was mainly assessed for cardiac differentiation. 
In chondrogenesis, the compressive magnetic stimulating relates to other non-magnetic studies demonstrating that a dynamic compressive loading applied by direct contact to the cells (non-magnetic) clearly enhances chondrogenesis, even in the absence of exogenous growth factors, suggesting that compression alone is sufficient to induce chondrogenesis [202,203]. Such dynamic compression triggers the transforming growth factor (TGF)- $\beta /$ SMAD signaling pathway, crucial in the maintenance of articular cartilage and the differentiation of MSCs into chondrocytes [204]. It directly echoes to the movements and forces transmitted through the axial skeleton that articular and vertebral cartilage are subjected to. Using magnetic forces to apply an external compression demonstrated as well an enhanced chondrogenic differentiation, using both static and dynamic compression [34,205-207].

In osteogenesis, mechanical stimulation is crucial as well, and a simple proof emanates from microgravity situations where the mechanical unloading of bones leads to their progressive degeneration and the limited differentiation of stem cells [208]. When using magnetic forces to apply compression at a distance, studies generally demonstrate an enhanced osteogenesis, under both static (i.e. with a permanent magnet) or dynamic (i.e. with a transitory magnetic field) stimulation $[113,206]$. The nanoparticles might play a role in this phenomenon as their presence alone sometimes drives the differentiation [188-191]. Jiang et al. evidenced elevated ALP activity, calcium deposition, and expressions of collagen type I and osteocalcin at both mRNA and protein levels under magnetic compression [113].

In cardiomyogenesis, non-magnetic tensile strain has been shown to promote cardiac differentiation [209]. Remarkably, cyclic stretching applied magnetically to embryonic stem cells (ESCs) was recently shown to also drive their differentiation toward the mesodermal cardiac pathway [36].

Finally, it is worth mentioning that another magnetic approach to improve cellular differentiation is to trigger mechanotransduction pathways. In this case, the nanoparticles are not internalized in the cells but anchored to the surface via molecules such as RGD or TREK1. The manipulation or mechanical activation of the mechanosensitive receptors was shown to induce the differentiation toward an osteogenic lineage as for example indicated by the upregulation of RUNX2 synthesis and ALP activity [210-213].

Table 2: Effects of magneto-mechanical stimulation on stem cell differentiation. Differentiation (diff.), nanoparticles (NPs), experiment (exp.), references (ref.), human mesenchymal stem cells (hMSCs), rat 
mesenchymal stem cells (rMSCs), mouse embryonic stem cells (mESCs), lipoprotein lipase (LPL), alkaline phosphatase (ALP), glycosaminoglycans (GAG).

\begin{tabular}{|c|c|c|c|c|c|c|c|c|}
\hline $\begin{array}{l}\text { Diff. } \\
\text { pathway }\end{array}$ & $\begin{array}{l}\text { Impact on } \\
\text { diff. }\end{array}$ & $\begin{array}{l}\text { Cell } \\
\text { type }\end{array}$ & $\begin{array}{l}\text { NPs structure } \\
\text { (core/coating) }\end{array}$ & $\begin{array}{l}\text { Iron / } \\
\text { cell } \\
\text { (pg) }\end{array}$ & $\begin{array}{l}\text { Exp. } \\
\text { time } \\
\text { (days) }\end{array}$ & $\begin{array}{l}\text { Type of magnetic field } \\
\text { stimulus }\end{array}$ & Effect & Ref. \\
\hline Adipo & Enhanced & hMSCs & Ferucarbotran & $\begin{array}{l}30-55 \\
\text { (day } 7 \text { ) }\end{array}$ & 21 & $\begin{array}{l}\text { Static } \\
\text { (compressive) }\end{array}$ & $\begin{array}{l}\uparrow L P L \text { gene expression } \\
\uparrow \text { PPAR } y \text { gene expression }\end{array}$ & {$[214]$} \\
\hline \multirow[t]{6}{*}{ Osteo } & Positive & hMSCs & Ferucarbotran & $\begin{array}{l}30-55 \\
\text { (day } 7 \text { ) }\end{array}$ & 21 & $\begin{array}{l}\text { Static } \\
\text { (compressive) }\end{array}$ & = ALP gene expression & [214] \\
\hline & Enhanced & rMSCs & $\begin{array}{l}\text { Magnetite/ } \\
\text { BSA }\end{array}$ & - & 21 & $\begin{array}{l}\text { Static } \\
\text { (compressive) }\end{array}$ & $\begin{array}{l}\text { 个 ALP activity } \\
\uparrow \text { calcium deposition } \\
\uparrow \text { collagen I and osteocalcin gene and } \\
\text { protein expression }\end{array}$ & [113] \\
\hline & & hMSCs & $\begin{array}{l}\text { Magnetite/ } \\
\text { dextran }\end{array}$ & - & 21 & $\begin{array}{l}\text { Oscillating } \\
\text { (compressive, } 2 \mathrm{~Hz} \text { and } \\
0.2 \mathrm{~mm} \text { displacement) }\end{array}$ & $\uparrow$ calcium deposition & [206] \\
\hline & & hMSCs & $\begin{array}{l}\text { Iron oxide/ } \\
\text { RGD or TREK-1 }\end{array}$ & - & 28 & $\begin{array}{l}\text { Cyclic } \\
\text { (mechanotransduction, } \\
1 \mathrm{~h} / \text { day, max. } 25 \mathrm{mT}, 1 \\
\mathrm{~Hz} \text { ) }\end{array}$ & $\begin{array}{l}\text { 个 ALP activity } \\
\uparrow \text { calcium deposition }\end{array}$ & [210] \\
\hline & & hMSCs & $\begin{array}{l}\text { Iron oxide/ } \\
\text { TREK-1 }\end{array}$ & - & 21 & $\begin{array}{l}\text { Cyclic } \\
\text { (mechanotransduction, } \\
1 \mathrm{~Hz} \text { ) }\end{array}$ & $\begin{array}{l}\text { 个 Opn, Cbfa-1 gene expression (day 7) } \\
\text { 个 collagen I and II gene expression } \\
\text { and synthesis as well as proteoglycan } \\
\text { synthesis (day 21) }\end{array}$ & [212] \\
\hline & & hMSCs & $\begin{array}{l}\text { Iron oxide/ } \\
\text { PEG-RGD }\end{array}$ & - & 7 & $\begin{array}{l}\text { Oscillatory } \\
\text { (mechanotransduction, } \\
0.1 \mathrm{~Hz} \text { ) }\end{array}$ & $\begin{array}{l}\text { 个 RUNX2 synthesis } \\
\text { 个 ALP activity }\end{array}$ & [213] \\
\hline \multirow[t]{5}{*}{ Chondro } & Positive & hMSCs & Ferucarbotran & $\begin{array}{l}30-55 \\
\text { (day } 7)\end{array}$ & 14 & $\begin{array}{l}\text { Static } \\
\text { (compressive) }\end{array}$ & = collagen II gene expression & {$[214]$} \\
\hline & Enhanced & hMSCs & $\begin{array}{l}\text { Bacterial } \\
\text { magnetite }\end{array}$ & $\sim 60$ & 21 & $\begin{array}{l}\text { static and/or magnet- } \\
\text { derived shear stress } \\
(0.25 \mathrm{mT}, 1 \mathrm{~h} / \text { day for } 5 \\
\text { days })\end{array}$ & $\begin{array}{l}\uparrow \text { GAG and collagen synthesis } \\
\uparrow \text { collagen II, aggrecan and Sox9 gene } \\
\text { expression }\end{array}$ & {$[205]$} \\
\hline & & hMSCs & $\begin{array}{l}\text { Maghemite/ } \\
\text { citrate }\end{array}$ & 5 & 25 & $\begin{array}{l}\text { Static } \\
\text { (compaction) }\end{array}$ & $\begin{array}{l}\uparrow \text { collagen II gene expression } \\
=\text { aggrecan gene expression }\end{array}$ & [34] \\
\hline & & hMSCs & $\begin{array}{l}\text { Magnetite/ } \\
\text { dextran }\end{array}$ & - & 28 & $\begin{array}{l}\text { Oscillating } \\
\text { (compressive, } 2 \mathrm{~Hz} \text { and } \\
0.2 \mathrm{~mm} \text { displacement) }\end{array}$ & $\begin{array}{l}\text { 个 proteoglycan content (Safranin-O } \\
\text { staining) }\end{array}$ & [206] \\
\hline & & rMSCs & Iron oxide & - & 21 & $\begin{array}{l}\text { Pulsed } \\
\text { (50 Hz, } 20 \mathrm{mT} \text {, for } 30 \\
\text { min at } 24 \text {-h intervals) }\end{array}$ & $\begin{array}{l}\uparrow \mathrm{GAG} \text { content } \\
\uparrow \text { aggrecan, collagen II, and Sox9 gene } \\
\text { expression }\end{array}$ & [207] \\
\hline Myogenic & Enhanced & ESCs & Iron oxide & - & 5 & $\begin{array}{l}\text { Pulsed } \\
\text { (12 Hz, } 0.1 \mathrm{mT}, 6 \mathrm{~h} / \text { day } \\
\text { for } 5 \text { days) }\end{array}$ & $\uparrow$ MyoG and Myh2 gene expression & [215] \\
\hline Cardiac & Enhanced & mESCs & $\begin{array}{l}\text { Maghemite/ } \\
\text { citrate }\end{array}$ & 3 & 10 & $\begin{array}{l}\text { Static and cyclic } \\
\text { (tensile, } 1 \mathrm{~Hz}, 10 \% \\
\text { amplitude) }\end{array}$ & $\begin{array}{l}\text { 个 Nkx2.5, T, Sox17, Gata4 and Gata6 } \\
\text { gene expression (day 5) } \\
\uparrow \text { Tnnt2, Myh6 and Myl2 gene } \\
\text { expression (day 10) } \\
\text { 个 Actc1 gene expression (day 10, } \\
\text { cyclic stretching only) }\end{array}$ & [36] \\
\hline
\end{tabular}




\section{Degradation of magnetic nanoparticles internalized in cells}

The first step for most biomedical applications of magnetic nanoparticles is to internalize them inside the cells, where they are to be left within. Consequently, one mandatory step prior to clinical translation is to explore their long-term intracellular fate and understand whether they behave as a single indissoluble unit or if they can, in the contrary, be affected by the surrounding biological environment. Primary concerns associated to a possible biodegradation would be both the risk of a decreased magnetic response precluding long-term applicability and the potential toxicity brought by the release of free iron ions.

\subsection{Quantification of the nanoparticle degradation}

\subsubsection{Qualitative assessments in vivo}

In vivo studies observing the assimilation cycle of magnetic nanoparticles administered to a mammalian organism showed they follow a typical course toward diverse organs [174,216-223]. First, upon injection, the nanoparticles are mostly taken up by the macrophages of the liver, spleen, kidney, and bone marrow, where iron content peaks within hours [174,216,218-223]. The tissue-resident macrophages of the liver are the Kupffer cells, which are highly involved in iron metabolism as they handle hemoglobin recycling upon red blood cell ingestion, with subsequent return of iron to the circulation [224]. Upon internalization into macrophages, a fusion takes place between the phagosomes and the lysosomal compartments, where the nanoparticles are subjected to a progressive acid-induced degradation [167,225-227]. It is believed that their coating is first dissolved by lysosomal proteases and the internal iron oxides are released followed by rapid dissolution in the acidic environment.

\subsubsection{Precise in vitro quantification via magnetometry}

These in vivo studies provide qualitative measurements and are close to clinic reality; however, due to their high degree of complexity, precise quantification of degradation is difficult. An alternative is proposed by in vitro studies performed on a defined pool of cells. These in cellulo methodologies have the advantage of including the proteins found in the biological environment, and among them, the proteins related to iron metabolism. Measurements of magnetism can be performed on this pool of cells and allow the quantitative monitoring of the nanoparticles' integrity in the long-term (over months) using techniques such as superconducting quantum interference device (SQUID), vibrating sample magnetometry (VSM), AC susceptibility, and magnetophoresis [41,176,177,228,229]. All rely on the measurement of the cells' magnetic moment, direct structural fingerprint of the nanoparticles in situ. 
These characterization methods can be correlated with inductively coupled plasma mass spectroscopy (ICP-MS) or colorimetric based UV-visible absorption quantification techniques that determine total iron content. Both approaches are not only complementary but also mandatory to provide a reliable measurement of the degradation extent: Decreasing values of cellular magnetism indicate a degradation of the nanoparticles only if total iron remains constant.

\subsubsection{Evidence of a progressive degradation for varying nanoparticles structures}

Studies assessing the transformations of magnetic nanoparticles into stem cells have shown that the nanoparticles are most commonly endocytosed in endosomes that then fuse with lysosomes, where an acid-induced degradation takes place [36,41,176,229]. This progressive degradation has been quantitatively measured in cellulo, in a stem cell-spheroid model [41,176,229]. Under this specific culture model the stem cells stop dividing, start producing an extracellular matrix-rich environment, can be cultured for extend time frames (superior to a month), and can easily be handled due to their cohesive structure in the form of aggregates. The magnetization of these aggregates can be analyzed using the magnetometry methods described previously [41,176], allowing long-term monitoring of the nanoparticles' transformations, or even in real-time using a magnetic sensor specifically adapted for these studies [229]. Using this model, the progressive degradation of a panel of nanostructures was demonstrated, including rock-like iron oxide nanoparticles $(8-9 \mathrm{~nm})$ made by co-precipitation, iron oxide nanocubes $(20 \mathrm{~nm})$ and gold-magnetic nanodimers $(10 \mathrm{~nm}$ iron oxide spheres attached to $3.5 \mathrm{~nm}$ gold spheres) made by thermal decomposition, or iron oxide flower-like multicores ( $25 \mathrm{~nm}$ ) made by polyol synthesis [41,42] (Fig. 2A-D). The degradation rate was shown to be dose dependent, with a higher nanoparticle internalization engendering a lower degradation rate [176]. For a low dose (2 pg iron/cell), it was even shown that up to $90 \%$ degradation was reached within a month [41] for small nanoparticles made by co-precipitation. Intracellular observations at the nanoscale by transmission electron microscopy (TEM) provided confirmation via direct observations of morphological alterations.

\subsection{Degradation-induced toxicity?}

The degradation of magnetic nanoparticles is first supposed to engender the release of free iron ions inside the cells [158]. If kept in the unbound redox active state, these released ions can trigger toxic events by releasing reactive oxygen species (ROS) in their surroundings. Or they can join the intracellular iron pool and integrate into the innate iron metabolic pathway, and typically be stored within the ferritin protein (Fig. 2E-F). Later on, it can be transferred to plasma transferrin for transport within the entire organism and ultimately used for hemoglobin synthesis after uptake into erythroid precursor cells [230]. 
Iron-mediated toxicity is supposed to happen mainly in case of iron overload, whenever the normal capacity for handling of iron is exceeded. In this case, the unbound ferrous $\left(\mathrm{Fe}^{2+}\right)$ ions then available will react with hydrogen peroxide $\left(\mathrm{H}_{2} \mathrm{O}_{2}\right)$ and create a ROS hydroxyl radical $(\bullet \mathrm{OH})$ as described by the Fenton reaction. Such ROS-mediated toxic mechanism is the one considered as having a major role in magnetic nanoparticles-induced toxicity [231]. The potential of nanoparticles to induce genotoxicity is for example attributed to the generation of the free radical $\mathrm{HO}$, which interacts with DNA to form 8 hydroxyl-2'-deoxyguanosine that ultimately leads to DNA damage.

For applications such as MRI imaging, the progressive degradation of the nanoparticles and its associated loss of MRI signal might be a concern for the long-term follow-up of implanted cells or tissues; however, for other applications, such as the treatment of anemia, it might be exploited under a curative approach $[232,233]$. Indeed, a drug commercialized under the trademark Feraheme has been approved as an iron supplement. It consists of superparamagnetic iron oxides that are coated with a carbohydrate shell and, as they degrade, the released iron integrates the patient's metabolism. The nanoparticles degradability can also be exploited under a curative approach for cancer treatment. The toxicity engendered by nanoparticles degradation is then used to kill cancerous cells via ferroptosis, either by injecting a high dose of nanoparticles (with or without applying an additional constraint) or by suppressing cellular characteristics [234].

\subsection{Adaptation of iron metabolism to manage the released ions}

Iron metabolism is tightly regulated to maintain homeostasis and reduce toxicity. The balance between iron import and export involves several proteins that are believed to manage the arrival of ionic iron produced from nanoparticles degradation as well. When nanoparticles are degraded in the lysosomes, the ionic iron released can be either stored within the ferritin or transferred into the cytoplasm via the divalent metal-ion transporter 1 (DMT1), where it will either similarly be stored in the ferritin or join the mitochondrial iron pool for its use in cellular processes [235] (Table 3 and Fig. 2G). Ferritin can store up to 4500 iron atoms and consists in both a light and heavy chain (FtL and FtH, respectively). The subunit FtH oxidizes ferrous iron ( $\mathrm{Fe} 2+)$ into ferric iron $(\mathrm{Fe} 3+)$ before its storage within the subunit FtL. Ionic iron can also be exported via the ferroportin to be used for metabolic functions. The activity of ferroportin is inhibited by hepcidin, a small peptide hormone secreted by the liver into the bloodstream and regulated by the iron level. Hepcidin binds to ferroportin and triggers its internalization and degradation. In the bloodstream, the released iron is loaded onto the transferrin as a carrier and then internalized by the target cells via the transferrin receptor. There are two receptors for transferrin: receptor 1 (TfR1) and receptor 2 (TfR2). Receptor 2 was isolated in 1999 by Kawabata et al. and identified as a second transferrin receptor [236]. It is less abundant than TfR1 and seems to be less 
involved in the transport of iron [237]. Therefore TfR 1 remains the main transferrin receptor. The expression of proteins involved in cellular iron import and export is transcriptionally regulated to preserve iron homeostasis. How the free iron ions released in the intracellular environment upon nanoparticle degradation can change the expression level of the iron metabolism specific proteins has been quantified in several studies performed both in vitro and in vivo with various nanoparticles types (Table 3). Protein expression was studied by gene expression (mRNAs, qPCR, microarray) or proteomics (western blot, ELISA, flow cytometry). First and foremost, ferritin expression is increased most certainly because the cells need an amplified iron storage capacity [41,221,238-247]. Concomitantly, some studies have shown that TfR1 expression decreases to limit iron uptake from the bloodstream [238,246,248,249], while ferroportin expression increases [41,239,241,244,246].

Table 3: Impact of magnetic nanoparticles on iron metabolism assessed in cell lines (macrophages and other specialized cells), MSCs, and in vivo. Citric acid (CIT), dextran (DEX), dimercaptosuccinicacid (DMSA), Transferrin receptor (TfR), divalent metal transporter-1 (DMT1).

\begin{tabular}{|c|c|c|c|c|c|c|c|}
\hline Cell type & Cell type & $\begin{array}{l}\text { Nanoparticles } \\
\text { (core size /coating) }\end{array}$ & $\begin{array}{l}\text { Iron / } \\
\text { cell (pg) }\end{array}$ & $\begin{array}{l}\text { Experimental } \\
\text { time }\end{array}$ & $\begin{array}{l}\text { Analytical } \\
\text { method }\end{array}$ & Effects & Ref. \\
\hline \multirow[t]{5}{*}{ Immune } & $\begin{array}{l}\text { macrophage } \\
\text { raw264.7 }\end{array}$ & $\begin{array}{l}\text { Maghemite } \\
10 \mathrm{~nm} / \mathrm{DMSA}\end{array}$ & $7-25$ & 24 to $72 \mathrm{~h}$ & $\begin{array}{l}\text { qPCR, } \\
\text { Western Blot }\end{array}$ & $\begin{array}{l}\text { RNA: L-ferritin and ferroportin } \uparrow \\
\text { proteins: L-ferritin } \uparrow \text { ferroportin }=\end{array}$ & [239] \\
\hline & $\begin{array}{l}\text { macrophage } \\
\text { NCTC }\end{array}$ & $\begin{array}{l}\text { Maghemite } \\
7 \mathrm{~nm} / \mathrm{CIT} \text { or DEX }\end{array}$ & - & $96 \mathrm{~h}$ & $\begin{array}{l}\text { qPCR, } \\
\text { Western Blot }\end{array}$ & $\begin{array}{l}\text { TfR } \downarrow \\
\text { DMT1, Ferroportin } \uparrow \\
\text { L-ferritin } \uparrow\end{array}$ & [246] \\
\hline & $\begin{array}{l}\text { macrophage } \\
\text { THP1-M1 } \\
\text { \& THP1-M2 }\end{array}$ & $\begin{array}{l}\text { Maghemite } \\
7 \mathrm{~nm} / \mathrm{CIT} \text { or DEX }\end{array}$ & - & $96 \mathrm{~h}$ & $\begin{array}{l}\text { qPCR, } \\
\text { Western Blot }\end{array}$ & $\begin{array}{l}\text { TfR } \downarrow \\
\text { DMT1, Ferroportin } \downarrow(M 1)=(M 2) \\
\text { L-ferritin } \uparrow\end{array}$ & [246] \\
\hline & macrophage & Ferumoxide & 22 & $4 \& 9$ weeks & $\begin{array}{l}\text { qPCR, } \\
\text { Western Blot }\end{array}$ & $\begin{array}{l}\text { TfR = } \\
\text { ferritin }\end{array}$ & [238] \\
\hline & $\begin{array}{l}\text { monocyte } \\
\text { THP } 1\end{array}$ & Ferucarbotran & - & $48 \mathrm{~h}$ & $\begin{array}{l}\text { Flow } \\
\text { cytometry }\end{array}$ & $\begin{array}{l}\text { Ferroportin } \uparrow \\
\text { ferritin } \uparrow\end{array}$ & [244] \\
\hline \multirow[t]{2}{*}{$\begin{array}{l}\text { Cancer } \\
\text { cells }\end{array}$} & HeLa & Ferumoxide & 20 & 4 \& 9 weeks & $\begin{array}{l}\text { qPCR, } \\
\text { Western Blot }\end{array}$ & $\begin{array}{l}\text { TfR } \downarrow \text { the first days } \\
\text { ferritin } \uparrow \text { from day } 7\end{array}$ & [238] \\
\hline & U-937 & Ferucarbotran & - & $48 \mathrm{~h}$ & $\begin{array}{l}\text { Flow } \\
\text { cytometry }\end{array}$ & ferritin $\uparrow$ & [244] \\
\hline \multirow[t]{2}{*}{$\frac{\text { Neural }}{\text { cells }}$} & $\begin{array}{l}\text { oligodendrocyte } \\
\text { rat brain }\end{array}$ & $\begin{array}{l}\text { Maghemite } \\
2-20 \mathrm{~nm} / \mathrm{DMSA}\end{array}$ & - & $48 \mathrm{~h}$ & Western Blot & L-ferritin $\uparrow$ & [242] \\
\hline & $\begin{array}{l}\text { astrocytes } \\
\text { rat brain }\end{array}$ & $\begin{array}{l}\text { maghemite } \\
10 \mathrm{~nm} / \mathrm{DMSA}\end{array}$ & - & 7 days & Western Blot & ferritin $\uparrow$ & [243] \\
\hline \multirow[t]{5}{*}{$\frac{\text { Stem }}{\text { cells }}$} & hMSC & $\begin{array}{l}\text { Maghemite } \\
8 \mathrm{~nm} / \text { citrate }\end{array}$ & 2 & 25 days & $\mathrm{qPCR}$ & $\begin{array}{l}\mathrm{L} \text {-ferritin } \uparrow \mathrm{H} \text {-ferritin= } \\
\text { ferroportin } \uparrow \mathrm{DMT} 1=\end{array}$ & [41] \\
\hline & hMSC & $\begin{array}{l}\text { Ferumoxide } \\
120-150 \mathrm{~nm} / \text { dextran }\end{array}$ & 45 & $4 \& 9$ weeks & $\begin{array}{l}\text { qPCR, } \\
\text { Western Blot }\end{array}$ & $\begin{array}{l}\text { TfR } \downarrow \text { the } 14 \text { first days } \\
\text { ferritin } \uparrow \text { from day } 14\end{array}$ & [238] \\
\hline & hMSC & Ferumoxide & - & - & $\begin{array}{l}\text { gene } \\
\text { microarray }\end{array}$ & $\begin{array}{l}\text { TfR }= \\
\text { ferritin } \uparrow\end{array}$ & [240] \\
\hline & rMSCs & Ferucarbotran & $<25$ & - & $\begin{array}{l}\text { Flow } \\
\text { cytometry }\end{array}$ & $\mathrm{TfR} \uparrow$ & [250] \\
\hline & $\begin{array}{l}\text { neural stem cells } \\
\text { (mice) }\end{array}$ & Ferumoxide & - & 7 days & qPCR & TfR $\downarrow$ & [248] \\
\hline \multirow[t]{4}{*}{$\underline{\text { In vivo }}$} & mice & $\begin{array}{l}\text { Maghemite } \\
7 \mathrm{~nm} / \mathrm{CIT}\end{array}$ & - & $24 \mathrm{~h}$ & $\begin{array}{l}\text { Western Blot, } \\
\text { TEM }\end{array}$ & $\begin{array}{l}\text { Proteins: L-ferritin } \uparrow \\
\text { Images: Ferritin } \uparrow\end{array}$ & [246] \\
\hline & mice & $\begin{array}{l}\text { Maghemite } \\
8 \mathrm{~nm} / \text { glucose }\end{array}$ & - & 90 days & TEM & Ferritin $\uparrow$ & [221] \\
\hline & mice & $\begin{array}{l}\text { Maghemite } \\
21 \mathrm{~nm} / \mathrm{PEG}\end{array}$ & - & 14 days & TEM & Ferritin $\uparrow$ & [245] \\
\hline & rat & $\begin{array}{l}\text { Magnetite } \\
10 \mathrm{~nm} / \mathrm{PEG} \& \text { DMSA }\end{array}$ & - & 30 days & ELISA & ferritin, ferroportin and DMT1 $\uparrow$ & [241] \\
\hline
\end{tabular}




\begin{tabular}{|c|c|c|c|c|c|c|}
\hline frog & $\begin{array}{l}\text { Iron oxide } \\
13 \mathrm{~nm} / \mathrm{DMSA}\end{array}$ & - & $\sim 72 \mathrm{~h}$ & qPCR & $\begin{array}{l}\text { DMT1, Transferrin, Ferritin } \uparrow \\
\text { Hepcidin } \downarrow\end{array}$ & [247] \\
\hline frog & $\begin{array}{l}\text { Iron oxide } \\
132 \mathrm{~nm} / \mathrm{CIT}\end{array}$ & - & $\sim 72 \mathrm{~h}$ & qPCR & $\begin{array}{l}\text { DMT1, Transferrin = } \\
\text { Hepcidin, Ferritin } \uparrow\end{array}$ & [247] \\
\hline
\end{tabular}

\subsection{Long-term presence of magnetic nanoparticles within cells via chemical protection or biological recrystallization}

In some cases, it can be of interest to protect the nanoparticles from degradation [251]. Indeed, having nanoparticles that remain intact in the long-run might be highly positive if the stem cell-engineered tissue is to be re-stimulated in vitro, or even in vivo after implantation, or more simply imaged over long periods after grafting. With this in mind, the preservation of a magnetic core has been ensured via chemical processes, by grafting either a protective gold shell [42] or a PAA dense polymeric coating [176]. Other strategies have been applied [252], such as protecting the nanoparticles from lysosomal degradation by encapsulating them with poly(d,l-lactide-co-glycolide) (PLGA) [253], using magnetoliposomes that surrounds them with lipid bilayers [254], or again coating the surface of the nanoparticles with a thin silica layer, which induces surface passivation [255-258].

Biologically, we have recently demonstrated that human stem cells are themselves capable of iron recrystallization upon the degradation of previously internalized magnetic nanoparticles from chemical or biological (i.e. magnetosomes) origin [177,259]. This biosynthesis of magnetic nanoparticles took place in the case of 2D cultures of bone marrow-derived human stem cells that were either differentiated as adipocytes, osteocytes, or kept undifferentiated. The first step consisted in the degradation of the internalized magnetic nanoparticles (from day 0 to 1-3), but then, biosynthesis of new magnetic nanoparticles occurred (from day 1-3 to 21). This biosynthesis led to magnetization levels close to day 0 after 21 days of culture and, quite remarkably, it seemed to play a protective role as, even at high doses of intracellular iron, no toxicity was observed. By contrast, the same high dose was toxic when only the degradation of the nanoparticles (no recrystallization) was taking place. The magnetic biosynthesis of nanoparticles anew might then act as a "detoxification mechanism" in case of iron excess.

This biosynthesis can also be linked to previous observations of magnetic nanoparticles in the human body. Magnetic nanoparticles were first reported in the human brain in 1992 [260] and their existence has since been confirmed [261] and correlated with an effect of age (increased occurrence with increasing age observed in male subjects) [262,263] and to neurodegenerative diseases such as Alzheimer [264]. They have also been detected in other organs including the heart, spleen, liver, ethmoid bone, and tumors [265-268]. Their presence has been discussed and some studies indicated a biogenic origin whereas others supported an exogenic one, coming from the polluted environment via inhalation 
$[269,270]$. Both origins are most probably possible, and the recrystallization of magnetic nanoparticles recently observed in stem cells confirms that human cells are capable of such biosynthesis.

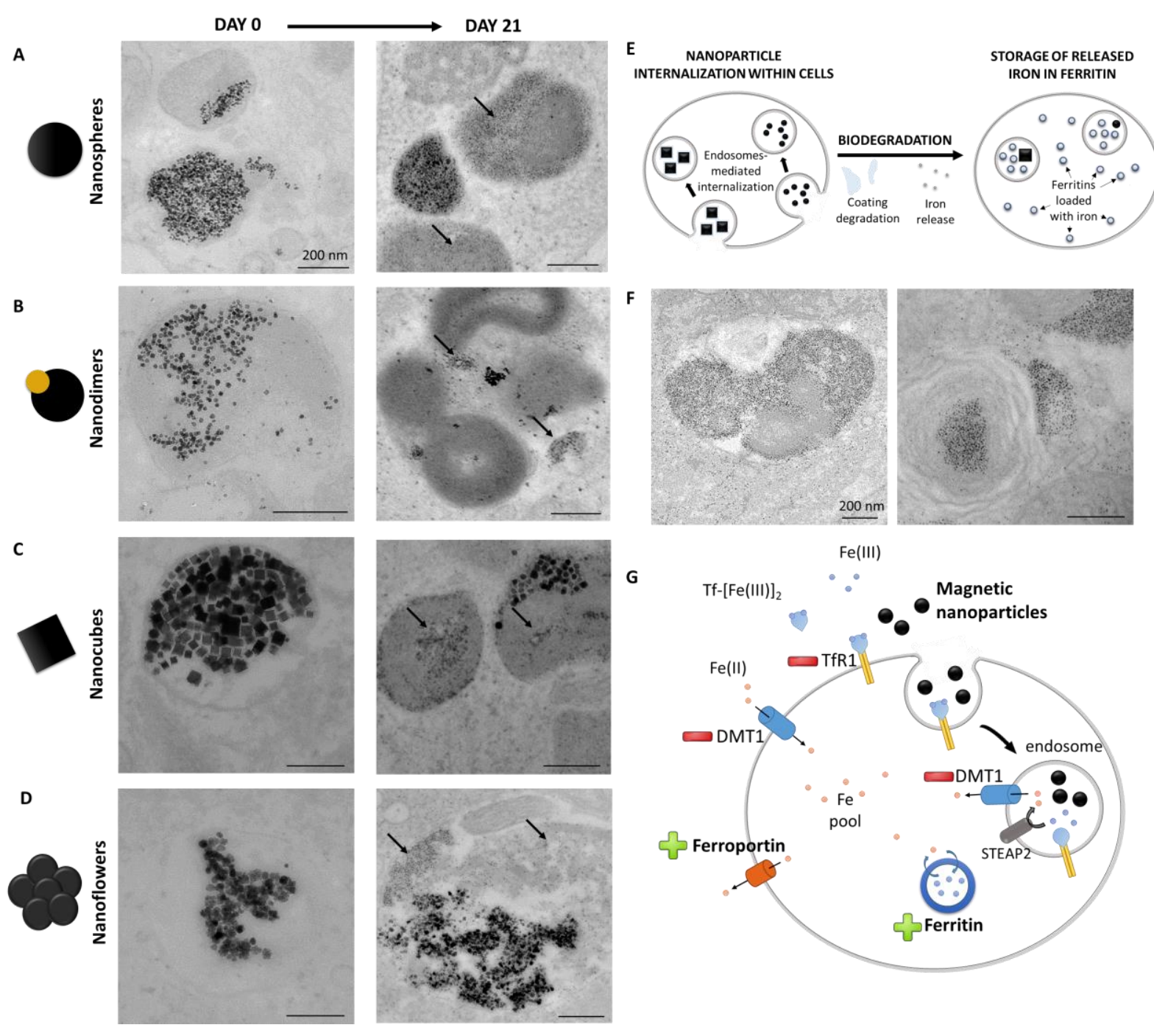

Fig. 2: In cellulo fate of magnetic nanoparticles. A-D) Representative TEM images of four types of nanoparticles; A: $8 \mathrm{~nm}$ in diameter rock-like nanoparticles made by coprecipitation, B: gold-iron nanodimers made by thermal decomposition, C: $20 \mathrm{~nm}$ nanocubes made by thermal decomposition, upon degradation only the gold remains intact, D: 25 multicore nanoparticles made by polyol synthesis. Left images display the nanoparticles right upon internalization within stem cells, their iron oxide core clearly appears in black. The nanoparticles remain intact following internalization and are located in the endosomes only. Right images show the nanoparticles after 3 to 4 weeks of culture, with some iron oxide cores still intact; however, most are degraded and the released iron is stored in ferritin proteins, which appear as $6 \mathrm{~nm}$ grey dots, and are indicated with black arrows. (Scale bars $=200 \mathrm{~nm}$ ) E) Representative schematic of magnetic nanoparticles' internalization within endosomal compartments in 
cells, then biodegradation of the coating and the magnetic core, followed by storage of the released iron in ferritin proteins. F) TEM images showing 5-6 nm grey dots in the endosomes and the cytoplasm of the cells upon nanoparticles' degradation, these dots are representative of ferritin proteins loaded with iron. (Scale bars $=200 \mathrm{~nm}$ ) G) Representative schematic of iron metabolism regulation upon nanoparticles' internalization in cells.

\section{Interplay between nanoparticles degradation, stem cell function, and iron metabolism}

Despite the acceptance and popularity for the applicative potential of magnetic nanoparticles in medicine, we must still resolve any issues regarding their impact and fate upon internalization within cells. The answer to this remaining question is not straight forward. Studies comparing several factors two by two exist, but a larger study that correlates dose of internalized nanoparticles, degradation rate, impact of the differentiation pathway and the modulation of expression of iron metabolism genes is still needed.

However, trends are starting to be defined such as the dose of internalized nanoparticles that has clearly been denoted as a factor indicative of potential toxicity (Fig. 3) [173,179-182]. High doses of nanoparticles seem linked to toxicity due to free iron ions released over the degradation of the nanoparticles $[158,231]$. The threshold between low and high dose has sometimes been defined, but is still controversial, with studies setting it at $100 \mathrm{pg}_{\mathrm{Fe}} / \mathrm{cell}$ while others limit it at $10 \mathrm{pg}_{\mathrm{Fe}} / \mathrm{cell}$. This emphasizes once again that the interaction and impact of nanoparticles on cells depend on a vast number of parameters that include nanoparticle features (core structure, coating) [44,164,165], as well as cell type, cell donor, and cell status (proliferation, confluence level) [159,168,177,178]. For stem cells undergoing differentiation, certain pathways seem more impacted than others, with toxicity observed under chondrogenesis and not under adipogenesis or osteogenesis for bone marrow stem cells at similarly high doses $[53,177,183-186]$. When considering the sensitive chondrogenic differentiation, remaining below $10 \mathrm{pg}_{\mathrm{Fe}} / \mathrm{cell}$ has proven a reasonable threshold to avoid toxicity $[173,177,184,185,196]$; however, each nanoparticle-cell system should be carefully evaluated independently to avoid any adverse effect.

Moreover, when considering clinical administration of high or frequently repeated doses, the normal body capacity to manage iron should be taken into account. Indeed, the total iron quantity in the body is tightly regulated and excess iron can be extremely toxic. Progressive clearance of iron excess is observed with rejection in the feces, similarly to endogenous iron [220], and some studies indicate full clearance within days [216], but here again, nanoparticles dose matters: a study assessed that under high 
concentrations complete removal from the tissue was not achieved after two months, whereas under low concentration they were eliminated within three weeks [271].

With increasing knowledge of nanoparticle impact on cells, tactics have emerged to avoid toxicity. A first approach is to protect the nanoparticles such as they do not incur degradation. For example, surrounding the iron oxide core with an inert shell, such as gold, has been shown to avoid degradation of iron oxide structures and to have little effect on the magnetic properties of the iron core $[42,272]$. Degradation has also been reduced by protecting the core with a silica shell or a lipid bilayer [252]. Negative effects coming from the production of ROS could also been countered by adding anti-oxidants to the culture medium $[173,252]$ or by combining them with other nanomaterials, such as $\mathrm{MnO}_{2}$ nanoparticles, which are potential contrast agents for MRI that have been shown to alleviate the oxidative environment by catalyzing the decomposition of $\mathrm{H}_{2} \mathrm{O}_{2}$ into $\mathrm{H}_{2} \mathrm{O}$ and $\mathrm{O}_{2}$ [273,274].

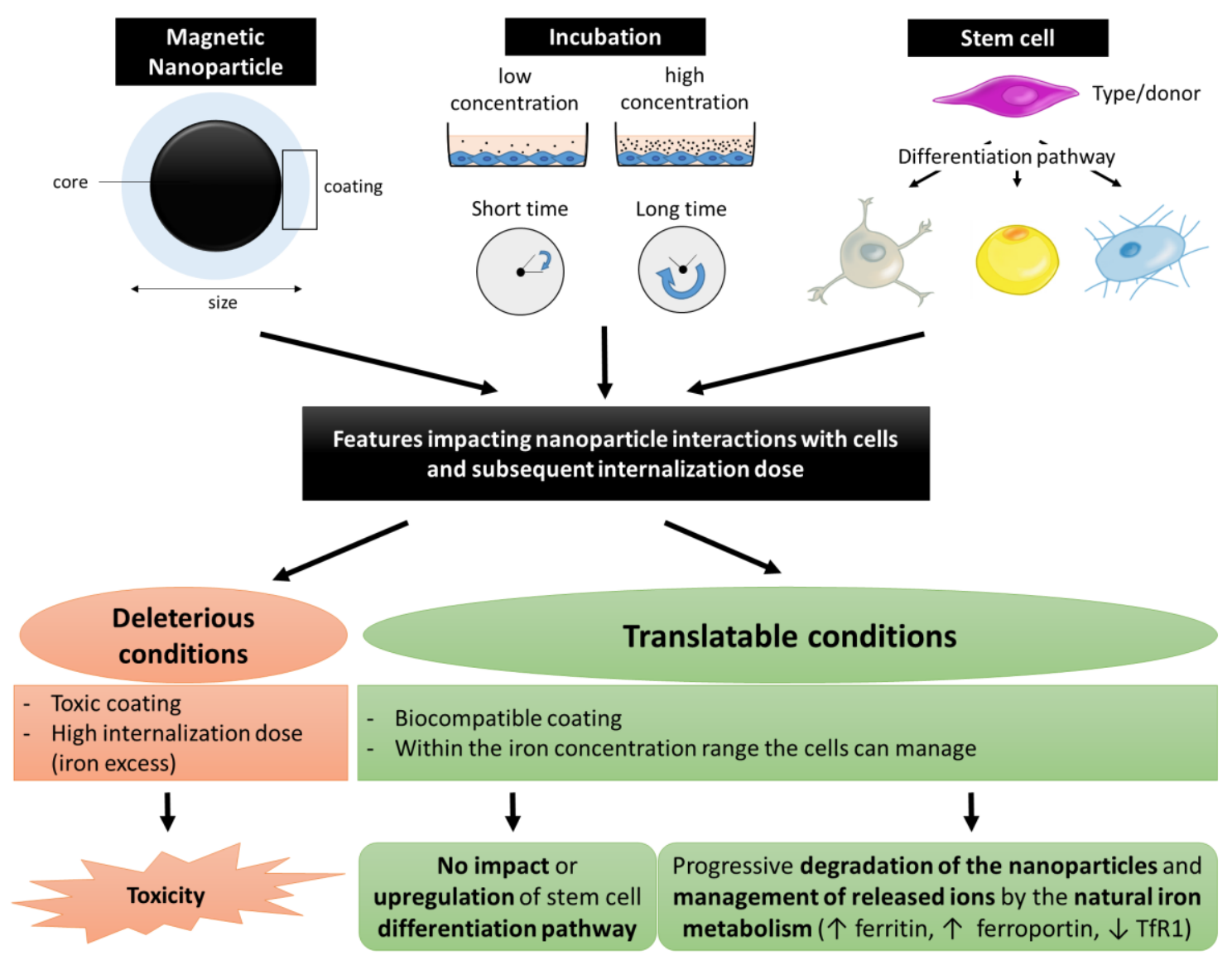

Fig. 3: The interplay between magnetic nanoparticles and cells depending on their features: from toxicity to enhanced stem cell differentiation. The features of the nanoparticles (core structure, coating type, size, and also shape), the incubation parameters (concentration, time), and the characteristics of the cells (type, donor, differentiation pathway) influence the interactions of the nanoparticles with the cells, and among them, the dose of internalized nanoparticles. It then either engenders toxicity when 
under deleterious conditions, such as an iron excess, or presents no impact or even an enhanced differentiation in the case of stem cells, by their presence alone or combined with magnetic biomechanical stimuli. In this case, the iron released over the degradation of the nanoparticles is incorporated to the natural metabolism of the organism.

To conclude, it is clear that iron oxide nanoparticles are bio-interacting; however, they are biocompatible and, despite rigorous assessments that should always be considered, we are right to consider them for biomedical applications, where their potential remains very high $[2,3]$. Besides the numerous possible applications in biomedical engineering linked to their magnetic properties, they have an additional advantage in regenerative medicine as they can positively drive stem cell differentiation by their simple presence or when used in concert with magnetic biomechanical stimuli, such as compression or stretching of the cells, as well as activation of signaling pathways via mechanotransduction [34,36,113,205-207,210-213]. They indeed seem to improve adipogenesis and osteogenesis by their presence only [188,190], further enhanced in case of stimulation [113,206,214]. Authorizations have already been obtained to make them available on the market for MRI imaging or as complements for anemia [2], paving the way for more and toward a wide demand that includes applications in tissue engineering, cancer treatment, and more to be discovered.

\section{Declarations of interest}

None.

\section{Acknowledgements}

This work was supported by the European Union (ERC-2014-CoG project MaTissE \#648779).

\section{References}

[1] J. Wolfram, M. Ferrari, Clinical cancer nanomedicine, Nano Today. 25 (2019) 85-98. https://doi.org/10.1016/j.nantod.2019.02.005.

[2] S.M. Dadfar, K. Roemhild, N.I. Drude, S. von Stillfried, R. Knüchel, F. Kiessling, T. Lammers, Iron oxide nanoparticles: Diagnostic, therapeutic and theranostic applications, Advanced Drug Delivery Reviews. 138 (2019) 302-325. https://doi.org/10.1016/j.addr.2019.01.005.

[3] N.T. Thanh, Clinical Applications of Magnetic Nanoparticles : From Fabrication to Clinical Applications, CRC Press, 2018. https://doi.org/10.1201/9781315168258. 
[4] N. Lee, D. Yoo, D. Ling, M.H. Cho, T. Hyeon, J. Cheon, Iron Oxide Based Nanoparticles for Multimodal Imaging and Magnetoresponsive Therapy, Chem. Rev. 115 (2015) 10637-10689. https://doi.org/10.1021/acs.chemrev.5b00112.

[5] B.H. Kim, N. Lee, H. Kim, K. An, Y.I. Park, Y. Choi, K. Shin, Y. Lee, S.G. Kwon, H.B. Na, J.-G. Park, T.-Y. Ahn, Y.-W. Kim, W.K. Moon, S.H. Choi, T. Hyeon, Large-Scale Synthesis of Uniform and Extremely Small-Sized Iron Oxide Nanoparticles for High-Resolution T1 Magnetic Resonance Imaging Contrast Agents, J. Am. Chem. Soc. 133 (2011) 12624-12631. https://doi.org/10.1021/ja203340u.

[6] H. Wei, O.T. Bruns, M.G. Kaul, E.C. Hansen, M. Barch, A. Wiśniowska, O. Chen, Y. Chen, N. Li, S. Okada, J.M. Cordero, M. Heine, C.T. Farrar, D.M. Montana, G. Adam, H. Ittrich, A. Jasanoff, P. Nielsen, M.G. Bawendi, Exceedingly small iron oxide nanoparticles as positive MRI contrast agents, Proc. Natl. Acad. Sci. U.S.A. 114 (2017) 2325-2330. https://doi.org/10.1073/pnas.1620145114.

[7] Y. Bao, J.A. Sherwood, Z. Sun, Magnetic iron oxide nanoparticles as T1 contrast agents for magnetic resonance imaging, J. Mater. Chem. C. 6 (2018) 1280-1290. https://doi.org/10.1039/C7TC05854C.

[8] R. Hachani, M. Lowdell, M. Birchall, A. Hervault, D. Mertz, S. Begin-Colin, N.T.K. Thanh, Polyol synthesis, functionalisation, and biocompatibility studies of superparamagnetic iron oxide nanoparticles as potential MRI contrast agents, Nanoscale. 8 (2016) 3278-3287. https://doi.org/10.1039/C5NR03867G.

[9] H.L. Chee, C.R.R. Gan, M. Ng, L. Low, D.G. Fernig, K.K. Bhakoo, D. Paramelle, Biocompatible Peptide-Coated Ultrasmall Superparamagnetic Iron Oxide Nanoparticles for In Vivo ContrastEnhanced Magnetic Resonance Imaging, ACS Nano. 12 (2018) 6480-6491. https://doi.org/10.1021/acsnano.7b07572.

[10] S. Miltenyi, W. Müller, W. Weichel, A. Radbruch, High gradient magnetic cell separation with MACS, Cytometry. 11 (1990) 231-238. https://doi.org/10.1002/cyto.990110203.

[11] B.D. Plouffe, S.K. Murthy, L.H. Lewis, Fundamentals and application of magnetic particles in cell isolation and enrichment: a review, Rep Prog Phys. 78 (2015) 016601. https://doi.org/10.1088/0034-4885/78/1/016601.

[12] N. Pamme, C. Wilhelm, Continuous sorting of magnetic cells via on-chip free-flow magnetophoresis, Lab Chip. 6 (2006) 974-980. https://doi.org/10.1039/b604542a.

[13] N. Pamme, Continuous flow separations in microfluidic devices, Lab Chip. 7 (2007) 1644-1659. https://doi.org/10.1039/B712784G.

[14] C.W. Shields, C.D. Reyes, G.P. López, Microfluidic cell sorting: a review of the advances in the separation of cells from debulking to rare cell isolation, Lab Chip. 15 (2015) 1230-1249. https://doi.org/10.1039/c4lc01246a.

[15] K.-A. Hyun, T.Y. Lee, S.H. Lee, H.-I. Jung, Two-stage microfluidic chip for selective isolation of circulating tumor cells (CTCS), Biosens Bioelectron. 67 (2015) 86-92. https://doi.org/10.1016/j.bios.2014.07.019.

[16] J.H. Myung, S. Hong, Microfluidic devices to enrich and isolate circulating tumor cells, Lab Chip. 15 (2015) 4500-4511. https://doi.org/10.1039/c5lc00947b.

[17] T.Y. Lee, K.-A. Hyun, S.-I. Kim, H.-I. Jung, An integrated microfluidic chip for one-step isolation of circulating tumor cells, Sensors and Actuators B: Chemical. 238 (2017) 1144-1150. https://doi.org/10.1016/j.snb.2016.05.163.

[18] C. Derec, C. Wilhelm, J. Servais, J.-C. Bacri, Local control of magnetic objects in microfluidic channels, Microfluid Nanofluid. 8 (2009) 123. https://doi.org/10.1007/s10404-009-0486-6.

[19] M. Johannsen, U. Gneveckow, B. Thiesen, K. Taymoorian, C.H. Cho, N. Waldöfner, R. Scholz, A. Jordan, S.A. Loening, P. Wust, Thermotherapy of prostate cancer using magnetic nanoparticles: feasibility, imaging, and three-dimensional temperature distribution, Eur. Urol. 52 (2007) 1653-1661. https://doi.org/10.1016/j.eururo.2006.11.023. 
[20] M. Johannsen, B. Thiesen, P. Wust, A. Jordan, Magnetic nanoparticle hyperthermia for prostate cancer, International Journal of Hyperthermia. 26 (2010) 790-795.

https://doi.org/10.3109/02656731003745740.

[21] K. Maier-Hauff, R. Rothe, R. Scholz, U. Gneveckow, P. Wust, B. Thiesen, A. Feussner, A. von Deimling, N. Waldoefner, R. Felix, A. Jordan, Intracranial Thermotherapy using Magnetic Nanoparticles Combined with External Beam Radiotherapy: Results of a Feasibility Study on Patients with Glioblastoma Multiforme, J Neurooncol. 81 (2007) 53-60. https://doi.org/10.1007/s11060-006-9195-0.

[22] K. Maier-Hauff, F. Ulrich, D. Nestler, H. Niehoff, P. Wust, B. Thiesen, H. Orawa, V. Budach, A. Jordan, Efficacy and safety of intratumoral thermotherapy using magnetic iron-oxide nanoparticles combined with external beam radiotherapy on patients with recurrent glioblastoma multiforme, J Neurooncol. 103 (2011) 317-324. https://doi.org/10.1007/s11060010-0389-0.

[23] S. Noh, S.H. Moon, T.-H. Shin, Y. Lim, J. Cheon, Recent advances of magneto-thermal capabilities of nanoparticles: From design principles to biomedical applications, Nano Today. 13 (2017) 61-76. https://doi.org/10.1016/j.nantod.2017.02.006.

[24] D. Niculaes, A. Lak, G.C. Anyfantis, S. Marras, O. Laslett, S.K. Avugadda, M. Cassani, D. Serantes, O. Hovorka, R. Chantrell, T. Pellegrino, Asymmetric Assembling of Iron Oxide Nanocubes for Improving Magnetic Hyperthermia Performance, ACS Nano. 11 (2017) 1212112133. https://doi.org/10.1021/acsnano.7b05182.

[25] G. Hemery, C. Genevois, F. Couillaud, S. Lacomme, E. Gontier, E. Ibarboure, S. Lecommandoux, E. Garanger, O. Sandre, Monocore vs. multicore magnetic iron oxide nanoparticles: uptake by glioblastoma cells and efficiency for magnetic hyperthermia, Mol. Syst. Des. Eng. 2 (2017) 629-639. https://doi.org/10.1039/C7ME00061H.

[26] A. Espinosa, J. Kolosnjaj-Tabi, A. Abou-Hassan, A.P. Sangnier, A. Curcio, A.K.A. Silva, R.D. Corato, S. Neveu, T. Pellegrino, L.M. Liz-Marzán, C. Wilhelm, Magnetic (Hyper)Thermia or Photothermia? Progressive Comparison of Iron Oxide and Gold Nanoparticles Heating in Water, in Cells, and In Vivo, Advanced Functional Materials. 28 (2018) 1803660. https://doi.org/10.1002/adfm.201803660.

[27] A. Plan Sangnier, S. Preveral, A. Curcio, A. K. A. Silva, C.T. Lefèvre, D. Pignol, Y. Lalatonne, C. Wilhelm, Targeted thermal therapy with genetically engineered magnetite magnetosomes@RGD: Photothermia is far more efficient than magnetic hyperthermia, Journal of Controlled Release. 279 (2018) 271-281. https://doi.org/10.1016/j.jconrel.2018.04.036.

[28] Z. Zhou, Y. Sun, J. Shen, J. Wei, C. Yu, B. Kong, W. Liu, H. Yang, S. Yang, W. Wang, Iron/iron oxide core/shell nanoparticles for magnetic targeting MRI and near-infrared photothermal therapy, Biomaterials. 35 (2014) 7470-7478. https://doi.org/10.1016/j.biomaterials.2014.04.063.

[29] G.R. Souza, J.R. Molina, R.M. Raphael, M.G. Ozawa, D.J. Stark, C.S. Levin, L.F. Bronk, J.S. Ananta, J. Mandelin, M.-M. Georgescu, J.A. Bankson, J.G. Gelovani, T.C. Killian, W. Arap, R. Pasqualini, Three-dimensional tissue culture based on magnetic cell levitation, Nat Nanotechnol. 5 (2010) 291-296. https://doi.org/10.1038/nnano.2010.23.

[30] B. Mattix, T.R. Olsen, Y. Gu, M. Casco, A. Herbst, D.T. Simionescu, R.P. Visconti, K.G. Kornev, F. Alexis, Biological magnetic cellular spheroids as building blocks for tissue engineering, Acta Biomaterialia. 10 (2014) 623-629. https://doi.org/10.1016/j.actbio.2013.10.021.

[31] F. Mazuel, M. Reffay, V. Du, J.-C. Bacri, J.-P. Rieu, C. Wilhelm, Magnetic Flattening of Stem-Cell Spheroids Indicates a Size-Dependent Elastocapillary Transition, Phys. Rev. Lett. 114 (2015) 098105. https://doi.org/10.1103/PhysRevLett.114.098105.

[32] L.J. Santos, R.L. Reis, M.E. Gomes, Harnessing magnetic-mechano actuation in regenerative medicine and tissue engineering, Trends in Biotechnology. 33 (2015) 471-479. https://doi.org/10.1016/j.tibtech.2015.06.006. 
[33] D. Fayol, G. Frasca, C. Le Visage, F. Gazeau, N. Luciani, C. Wilhelm, Use of magnetic forces to promote stem cell aggregation during differentiation, and cartilage tissue modeling, Adv. Mater. Weinheim. 25 (2013) 2611-2616. https://doi.org/10.1002/adma.201300342.

[34] N. Luciani, V. Du, F. Gazeau, A. Richert, D. Letourneur, C. Le Visage, C. Wilhelm, Successful chondrogenesis within scaffolds, using magnetic stem cell confinement and bioreactor maturation, Acta Biomater. 37 (2016) 101-110. https://doi.org/10.1016/j.actbio.2016.04.009.

[35] A.C. Daquinag, G.R. Souza, M.G. Kolonin, Adipose Tissue Engineering in Three-Dimensional Levitation Tissue Culture System Based on Magnetic Nanoparticles, Tissue Engineering Part C: Methods. 19 (2012) 336-344. https://doi.org/10.1089/ten.tec.2012.0198.

[36] V. Du, N. Luciani, S. Richard, G. Mary, C. Gay, F. Mazuel, M. Reffay, P. Menasché, O. Agbulut, C. Wilhelm, A 3D magnetic tissue stretcher for remote mechanical control of embryonic stem cell differentiation, Nat Commun. 8 (2017) 400. https://doi.org/10.1038/s41467-017-00543-2.

[37] B. Shah, P.T. Yin, S. Ghoshal, K.-B. Lee, Multimodal magnetic core-shell nanoparticles for effective stem-cell differentiation and imaging, Angew. Chem. Int. Ed. Engl. 52 (2013) 61906195. https://doi.org/10.1002/anie.201302245.

[38] P.D. Ray, B.-W. Huang, Y. Tsuji, Reactive oxygen species (ROS) homeostasis and redox regulation in cellular signaling, Cellular Signalling. 24 (2012) 981-990. https://doi.org/10.1016/j.cellsig.2012.01.008.

[39] L.M. Bystrom, M.L. Guzman, S. Rivella, Iron and Reactive Oxygen Species: Friends or Foes of Cancer Cells?, Antioxidants \& Redox Signaling. 20 (2012) 1917-1924. https://doi.org/10.1089/ars.2012.5014.

[40] S.J. Dixon, K.M. Lemberg, M.R. Lamprecht, R. Skouta, E.M. Zaitsev, C.E. Gleason, D.N. Patel, A.J. Bauer, A.M. Cantley, W.S. Yang, B. Morrison, B.R. Stockwell, Ferroptosis: An IronDependent Form of Nonapoptotic Cell Death, Cell. 149 (2012) 1060-1072. https://doi.org/10.1016/j.cell.2012.03.042.

[41] F. Mazuel, A. Espinosa, N. Luciani, M. Reffay, R. Le Borgne, L. Motte, K. Desboeufs, A. Michel, T. Pellegrino, Y. Lalatonne, C. Wilhelm, Massive Intracellular Biodegradation of Iron Oxide Nanoparticles Evidenced Magnetically at Single-Endosome and Tissue Levels, ACS Nano. 10 (2016) 7627-7638. https://doi.org/10.1021/acsnano.6b02876.

[42] F. Mazuel, A. Espinosa, G. Radtke, M. Bugnet, S. Neveu, Y. Lalatonne, G.A. Botton, A. AbouHassan, C. Wilhelm, Magneto-Thermal Metrics Can Mirror the Long-Term Intracellular Fate of Magneto-Plasmonic Nanohybrids and Reveal the Remarkable Shielding Effect of Gold, Advanced Functional Materials. 27 (2017) 1605997. https://doi.org/10.1002/adfm.201605997.

[43] A. Espinosa, M. Bugnet, G. Radtke, S. Neveu, G.A. Botton, C. Wilhelm, A. Abou-Hassan, Can magneto-plasmonic nanohybrids efficiently combine photothermia with magnetic hyperthermia?, Nanoscale. 7 (2015) 18872-18877. https://doi.org/10.1039/C5NR06168G.

[44] A. Plan Sangnier, A.B. Van de Walle, A. Curcio, R. Le Borgne, L. Motte, Y. Lalatonne, C. Wilhelm, Impact of magnetic nanoparticle surface coating on their long-term intracellular biodegradation in stem cells, Nanoscale. 11 (2019) 16488-16498.

https://doi.org/10.1039/C9NR05624F.

[45] E. Bull, S.Y. Madani, R. Sheth, A. Seifalian, M. Green, A.M. Seifalian, Stem cell tracking using iron oxide nanoparticles, Int J Nanomedicine. 9 (2014) 1641-1653. https://doi.org/10.2147/IJN.S48979.

[46] M. Hoehn, E. Küstermann, J. Blunk, D. Wiedermann, T. Trapp, S. Wecker, M. Föcking, H. Arnold, J. Hescheler, B.K. Fleischmann, W. Schwindt, C. Bührle, Monitoring of implanted stem cell migration in vivo: a highly resolved in vivo magnetic resonance imaging investigation of experimental stroke in rat, Proc. Natl. Acad. Sci. U.S.A. 99 (2002) 16267-16272. https://doi.org/10.1073/pnas.242435499.

[47] Jasmin, G.T. de Souza, R.A. Louzada, P.H. Rosado-de-Castro, R. Mendez-Otero, A.C. Campos de Carvalho, Tracking stem cells with superparamagnetic iron oxide nanoparticles: perspectives 
and considerations, Int J Nanomedicine. 12 (2017) 779-793.

https://doi.org/10.2147/IJN.S126530.

[48] J.W.M. Bulte, P. Walczak, M. Janowski, K.M. Krishnan, H. Arami, A. Halkola, B. Gleich, J. Rahmer, Quantitative "Hot-Spot" Imaging of Transplanted Stem Cells Using Superparamagnetic Tracers and Magnetic Particle Imaging, Tomography. 1 (2015) 91-97. https://doi.org/10.18383/j.tom.2015.00172.

[49] Y. Wang, C. Blanco-Andujar, Z. Zhi, P.-W. So, N.T.K. Thanh, J.C. Pickup, Multilayered nanocoatings incorporating superparamagnetic nanoparticles for tracking of pancreatic islet transplants with magnetic resonance imaging, Chem. Commun. (Camb.). 49 (2013) 72557257. https://doi.org/10.1039/c3cc43512a.

[50] J.W.M. Bulte, S.-C. Zhang, P. van Gelderen, V. Herynek, E.K. Jordan, I.D. Duncan, J.A. Frank, Neurotransplantation of magnetically labeled oligodendrocyte progenitors: Magnetic resonance tracking of cell migration and myelination, PNAS. 96 (1999) 15256-15261. https://doi.org/10.1073/pnas.96.26.15256.

[51] J.W.M. Bulte, T. Douglas, B. Witwer, S.-C. Zhang, E. Strable, B.K. Lewis, H. Zywicke, B. Miller, P. van Gelderen, B.M. Moskowitz, I.D. Duncan, J.A. Frank, Magnetodendrimers allow endosomal magnetic labeling and in vivo tracking of stem cells, Nature Biotechnology. 19 (2001) 11411147. https://doi.org/10.1038/nbt1201-1141.

[52] J.W.M. Bulte, T. Ben-Hur, B.R. Miller, R. Mizrachi-Kol, O. Einstein, E. Reinhartz, H.A. Zywicke, T. Douglas, J.A. Frank, MR microscopy of magnetically labeled neurospheres transplanted into the Lewis EAE rat brain, Magnetic Resonance in Medicine. 50 (2003) 201-205. https://doi.org/10.1002/mrm.10511.

[53] J.W.M. Bulte, L. Kostura, A. Mackay, P.V. Karmarkar, I. Izbudak, E. Atalar, D. Fritzges, E.R. Rodriguez, R.G. Young, M. Marcelino, M.F. Pittenger, D.L. Kraitchman, Feridex-labeled mesenchymal stem cells: cellular differentiation and MR assessment in a canine myocardial infarction model, Acad Radiol. 12 Suppl 1 (2005) S2-6.

[54] Z.G. Zhang, Q. Jiang, R. Zhang, L. Zhang, L. Wang, L. Zhang, P. Arniego, K.-L. Ho, M. Chopp, Magnetic resonance imaging and neurosphere therapy of stroke in rat, Annals of Neurology. 53 (2003) 259-263. https://doi.org/10.1002/ana.10467.

[55] P. HUA, Y.-Y. WANG, L.-B. LIU, J.-L. LIU, J.-Y. LIU, Y.-Q. YANG, S.-R. YANG, In vivo magnetic resonance imaging tracking of transplanted superparamagnetic iron oxide-labeled bone marrow mesenchymal stem cells in rats with myocardial infarction, Mol Med Rep. 11 (2015) 113-120. https://doi.org/10.3892/mmr.2014.2649.

[56] R.J.P. Skelton, S. Khoja, S. Almeida, S. Rapacchi, F. Han, J. Engel, P. Zhao, P. Hu, E.G. Stanley, A.G. Elefanty, M. Kwon, D.A. Elliott, R. Ardehali, Magnetic Resonance Imaging of Iron OxideLabeled Human Embryonic Stem Cell-Derived Cardiac Progenitors, STEM CELLS Translational Medicine. 5 (2016) 67-74. https://doi.org/10.5966/sctm.2015-0077.

[57] R.L. Azevedo-Pereira, B. Rangel, F. Tovar-Moll, E.L. Gasparetto, M. Attias, C. Zaverucha-doValle, Jasmin, R. Mendez-Otero, Superparamagnetic iron oxide nanoparticles as a tool to track mouse neural stem cells in vivo, Mol Biol Rep. 46 (2019) 191-198. https://doi.org/10.1007/s11033-018-4460-9.

[58] M. Xie, S. Luo, Y. Li, L. Lu, C. Deng, Y. Cheng, F. Yin, Intra-articular tracking of adipose-derived stem cells by chitosan-conjugated iron oxide nanoparticles in a rat osteoarthritis model, RSC Adv. 9 (2019) 12010-12019. https://doi.org/10.1039/C8RA09570A.

[59] B. Gleich, J. Weizenecker, Tomographic imaging using the nonlinear response of magnetic particles, Nature. 435 (2005) 1214-1217. https://doi.org/10.1038/nature03808.

[60] B. Zheng, T. Vazin, P.W. Goodwill, A. Conway, A. Verma, E. Ulku Saritas, D. Schaffer, S.M Conolly, Magnetic Particle Imaging tracks the long-term fate of in vivo neural cell implants with high image contrast, Scientific Reports. 5 (2015) 14055. https://doi.org/10.1038/srep14055. 
[61] N. Alon, T. Havdala, H. Skaat, K. Baranes, M. Marcus, I. Levy, S. Margel, A. Sharoni, O. Shefi, Magnetic micro-device for manipulating PC12 cell migration and organization, Lab Chip. 15 (2015) 2030-2036. https://doi.org/10.1039/c5lc00035a.

[62] A.J. El Haj, J.R. Glossop, H.S. Sura, M.R. Lees, B. Hu, S. Wolbank, M. van Griensven, H. Redl, J. Dobson, An in vitro model of mesenchymal stem cell targeting using magnetic particle labelling, J Tissue Eng Regen Med. 9 (2015) 724-733. https://doi.org/10.1002/term.1636.

[63] L.H.A. Silva, F.F. Cruz, M.M. Morales, D.J. Weiss, P.R.M. Rocco, Magnetic targeting as a strategy to enhance therapeutic effects of mesenchymal stromal cells, Stem Cell Research \& Therapy. 8 (2017) 58. https://doi.org/10.1186/s13287-017-0523-4.

[64] A. Ottersbach, O. Mykhaylyk, A. Heidsieck, D. Eberbeck, S. Rieck, K. Zimmermann, M. Breitbach, B. Engelbrecht, T. Brügmann, M. Hesse, A. Welz, P. Sasse, D. Wenzel, C. Plank, B. Gleich, M. Hölzel, W. Bloch, A. Pfeifer, B.K. Fleischmann, W. Roell, Improved heart repair upon myocardial infarction: Combination of magnetic nanoparticles and tailored magnets strongly increases engraftment of myocytes, Biomaterials. 155 (2018) 176-190. https://doi.org/10.1016/j.biomaterials.2017.11.012.

[65] A. Yanai, U.O. Häfeli, A.L. Metcalfe, P. Soema, L. Addo, C.Y. Gregory-Evans, K. Po, X. Shan, O.L. Moritz, K. Gregory-Evans, Focused magnetic stem cell targeting to the retina using superparamagnetic iron oxide nanoparticles, Cell Transplant. 21 (2012) 1137-1148. https://doi.org/10.3727/096368911X627435.

[66] E. Carenza, V. Barceló, A. Morancho, L. Levander, C. Boada, A. Laromaine, A. Roig, J. Montaner, A. Rosell, In vitro angiogenic performance and in vivo brain targeting of magnetized endothelial progenitor cells for neurorepair therapies, Nanomedicine. 10 (2014) 225-234. https://doi.org/10.1016/j.nano.2013.06.005.

[67] K. Nishida, N. Tanaka, K. Nakanishi, N. Kamei, T. Hamasaki, S. Yanada, Y. Mochizuki, M. Ochi, Magnetic targeting of bone marrow stromal cells into spinal cord: through cerebrospinal fluid, Neuroreport. 17 (2006) 1269-1272. https://doi.org/10.1097/01.wnr.0000227993.07799.a2.

[68] V. Vaněček, V. Zablotskii, S. Forostyak, J. Rưřička, V. Herynek, M. Babič, P. Jendelová, Š. Kubinová, A. Dejneka, E. Syková, Highly efficient magnetic targeting of mesenchymal stem cells in spinal cord injury, Int J Nanomedicine. 7 (2012) 3719-3730. https://doi.org/10.2147/IJN.S32824.

[69] R.-P. Zhang, L.-J. Wang, S. He, J. Xie, J.-D. Li, Effects of Magnetically Guided, SPIO-Labeled, and Neurotrophin-3 Gene-Modified Bone Mesenchymal Stem Cells in a Rat Model of Spinal Cord Injury, Stem Cells Int. 2016 (2016). https://doi.org/10.1155/2016/2018474.

[70] S. Oshima, M. Ishikawa, Y. Mochizuki, T. Kobayashi, Y. Yasunaga, M. Ochi, Enhancement of bone formation in an experimental bony defect using ferumoxide-labelled mesenchymal stromal cells and a magnetic targeting system, J Bone Joint Surg Br. 92 (2010) 1606-1613. https://doi.org/10.1302/0301-620X.92B11.23491.

[71] A. Kodama, N. Kamei, G. Kamei, W. Kongcharoensombat, S. Ohkawa, A. Nakabayashi, M. Ochi, In vivo bioluminescence imaging of transplanted bone marrow mesenchymal stromal cells using a magnetic delivery system in a rat fracture model, J Bone Joint Surg Br. 94 (2012) 9981006. https://doi.org/10.1302/0301-620X.94B7.28521.

[72] E.E. Mahmoud, G. Kamei, Y. Harada, R. Shimizu, N. Kamei, N. Adachi, N.A. Misk, M. Ochi, Cell Magnetic Targeting System for Repair of Severe Chronic Osteochondral Defect in a Rabbit Model, Cell Transplant. 25 (2016) 1073-1083. https://doi.org/10.3727/096368915X689613.

[73] G. Kamei, T. Kobayashi, S. Ohkawa, W. Kongcharoensombat, N. Adachi, K. Takazawa, H. Shibuya, M. Deie, K. Hattori, J.L. Goldberg, M. Ochi, Articular cartilage repair with magnetic mesenchymal stem cells, Am J Sports Med. 41 (2013) 1255-1264. https://doi.org/10.1177/0363546513483270.

[74] A. Nakabayashi, N. Kamei, T. Sunagawa, O. Suzuki, S. Ohkawa, A. Kodama, G. Kamei, M. Ochi, In vivo bioluminescence imaging of magnetically targeted bone marrow-derived mesenchymal stem cells in skeletal muscle injury model, J. Orthop. Res. 31 (2013) 754-759.

https://doi.org/10.1002/jor.22282. 
[75] S. Oshima, N. Kamei, T. Nakasa, Y. Yasunaga, M. Ochi, Enhancement of muscle repair using human mesenchymal stem cells with a magnetic targeting system in a subchronic muscle injury model, J Orthop Sci. 19 (2014) 478-488. https://doi.org/10.1007/s00776-014-0548-9.

[76] N. Kamei, M. Ochi, N. Adachi, M. Ishikawa, S. Yanada, L.S. Levin, G. Kamei, T. Kobayashi, The safety and efficacy of magnetic targeting using autologous mesenchymal stem cells for cartilage repair, Knee Surg Sports Traumatol Arthrosc. (2018). https://doi.org/10.1007/s00167-018-4898-2.

[77] E.A. Lee, H. Yim, J. Heo, H. Kim, G. Jung, N.S. Hwang, Application of magnetic nanoparticle for controlled tissue assembly and tissue engineering, Arch. Pharm. Res. 37 (2014) 120-128. https://doi.org/10.1007/s12272-013-0303-3.

[78] S. Yaman, M. Anil-Inevi, E. Ozcivici, H.C. Tekin, Magnetic Force-Based Microfluidic Techniques for Cellular and Tissue Bioengineering, Front. Bioeng. Biotechnol. 6 (2018). https://doi.org/10.3389/fbioe.2018.00192.

[79] H. Perea, J. Aigner, J.T. Heverhagen, U. Hopfner, E. Wintermantel, Vascular tissue engineering with magnetic nanoparticles: seeing deeper, J Tissue Eng Regen Med. 1 (2007) 318-321. https://doi.org/10.1002/term.32.

[80] D. Fayol, C. Le Visage, J. Ino, F. Gazeau, D. Letourneur, C. Wilhelm, Design of biomimetic vascular grafts with magnetic endothelial patterning, Cell Transplant. 22 (2013) 2105-2118. https://doi.org/10.3727/096368912X661300.

[81] C. Wilhelm, L. Bal, P. Smirnov, I. Galy-Fauroux, O. Clément, F. Gazeau, J. Emmerich, Magnetic control of vascular network formation with magnetically labeled endothelial progenitor cells., Biomaterials. 28 (2007) 3797-3806. https://doi.org/10.1016/j.biomaterials.2007.04.047.

[82] K. Shimizu, A. Ito, T. Yoshida, Y. Yamada, M. Ueda, H. Honda, Bone tissue engineering with human mesenchymal stem cell sheets constructed using magnetite nanoparticles and magnetic force, J. Biomed. Mater. Res. Part B Appl. Biomater. 82 (2007) 471-480. https://doi.org/10.1002/jbm.b.30752.

[83] Y. Yamamoto, A. Ito, M. Kato, Y. Kawabe, K. Shimizu, H. Fujita, E. Nagamori, M. Kamihira, Preparation of artificial skeletal muscle tissues by a magnetic force-based tissue engineering technique, J. Biosci. Bioeng. 108 (2009) 538-543.

https://doi.org/10.1016/j.jbiosc.2009.05.019.

[84] K. Shimizu, A. Ito, H. Honda, Mag-seeding of rat bone marrow stromal cells into porous hydroxyapatite scaffolds for bone tissue engineering, J. Biosci. Bioeng. 104 (2007) 171-177. https://doi.org/10.1263/jbb.104.171.

[85] A. Van de Walle, C. Wilhelm, N. Luciani, 3D Magnetic Stem Cell Aggregation and Bioreactor Maturation for Cartilage Regeneration, J Vis Exp. (2017). https://doi.org/10.3791/55221.

[86] D. Fayol, N. Luciani, C. Le Visage, F. Gazeau, C. Wilhelm, Methods for aggregation and differentiation of magnetized stem cells, (2013) FR2979634-A1; WO/2013/030393.

[87] B.R. Whatley, X. Li, N. Zhang, X. Wen, Magnetic-directed patterning of cell spheroids, J Biomed Mater Res A. 102 (2014) 1537-1547. https://doi.org/10.1002/jbm.a.34797.

[88] W.L. Haisler, D.M. Timm, J.A. Gage, H. Tseng, T.C. Killian, G.R. Souza, Three-dimensional cell culturing by magnetic levitation, Nat Protoc. 8 (2013) 1940-1949.

https://doi.org/10.1038/nprot.2013.125.

[89] H. Tseng, J.A. Gage, R.M. Raphael, R.H. Moore, T.C. Killian, K.J. Grande-Allen, G.R. Souza, Assembly of a three-dimensional multitype bronchiole coculture model using magnetic levitation, Tissue Eng Part C Methods. 19 (2013) 665-675. https://doi.org/10.1089/ten.TEC.2012.0157.

[90] G.R. Souza, J.R. Molina, R.M. Raphael, M.G. Ozawa, D.J. Stark, C.S. Levin, L.F. Bronk, J.S. Ananta, J. Mandelin, M.-M. Georgescu, J.A. Bankson, J.G. Gelovani, T.C. Killian, W. Arap, R. Pasqualini, Three-dimensional Tissue Culture Based on Magnetic Cell Levitation, Nat Nanotechnol. 5 (2010) 291-296. https://doi.org/10.1038/nnano.2010.23.

[91] N.J. Sniadecki, A tiny touch: activation of cell signaling pathways with magnetic nanoparticles, Endocrinology. 151 (2010) 451-457. https://doi.org/10.1210/en.2009-0932. 
[92] A.W. Orr, B.P. Helmke, B.R. Blackman, M.A. Schwartz, Mechanisms of mechanotransduction, Dev. Cell. 10 (2006) 11-20. https://doi.org/10.1016/j.devcel.2005.12.006.

[93] C.S. Chen, Mechanotransduction - a field pulling together?, J. Cell. Sci. 121 (2008) 3285-3292. https://doi.org/10.1242/jcs.023507.

[94] D.E. Ingber, Tensegrity: the architectural basis of cellular mechanotransduction, Annu. Rev. Physiol. 59 (1997) 575-599. https://doi.org/10.1146/annurev.physiol.59.1.575.

[95] P. Tseng, J.W. Judy, D. Di Carlo, Magnetic nanoparticle-mediated massively parallel mechanical modulation of single-cell behavior, Nat. Methods. 9 (2012) 1113-1119. https://doi.org/10.1038/nmeth.2210.

[96] F. Etoc, D. Lisse, Y. Bellaiche, J. Piehler, M. Coppey, M. Dahan, Subcellular control of RacGTPase signalling by magnetogenetic manipulation inside living cells, Nat Nanotechnol. 8 (2013) 193-198. https://doi.org/10.1038/nnano.2013.23.

[97] J. Han, B. Kim, J.-Y. Shin, S. Ryu, M. Noh, J. Woo, J.-S. Park, Y. Lee, N. Lee, T. Hyeon, D. Choi, B.S. Kim, Iron Oxide Nanoparticle-Mediated Development of Cellular Gap Junction Crosstalk to Improve Mesenchymal Stem Cells' Therapeutic Efficacy for Myocardial Infarction, ACS Nano. 9 (2015) 2805-2819. https://doi.org/10.1021/nn506732n.

[98] D. Seo, K.M. Southard, J. Kim, H.J. Lee, J. Farlow, J. Lee, D.B. Litt, T. Haas, A.P. Alivisatos, J. Cheon, Z.J. Gartner, Y. Jun, A Mechanogenetic Toolkit for Interrogating Cell Signaling in Space and Time, Cell. 165 (2016) 1507-1518. https://doi.org/10.1016/j.cell.2016.04.045.

[99] M. Rotherham, T. Nahar, T. Goodman, N. Telling, M. Gates, A.E. Haj, Magnetic Mechanoactivation of Wnt Signaling Augments Dopaminergic Differentiation of Neuronal Cells, Advanced Biosystems. 0 (n.d.) 1900091. https://doi.org/10.1002/adbi.201900091.

[100] K. Perica, A. Tu, A. Richter, J.G. Bieler, M. Edidin, J.P. Schneck, Magnetic Field-Induced T Cell Receptor Clustering by Nanoparticles Enhances T Cell Activation and Stimulates Antitumor Activity, ACS Nano. 8 (2014) 2252-2260. https://doi.org/10.1021/nn405520d.

[101] M.H. Cho, E.J. Lee, M. Son, J.-H. Lee, D. Yoo, J. Kim, S.W. Park, J.-S. Shin, J. Cheon, A magnetic switch for the control of cell death signalling in in vitro and in vivo systems, Nature Materials. 11 (2012) 1038-1043. https://doi.org/10.1038/nmat3430.

[102] M.B. Steketee, S.N. Moysidis, X.-L. Jin, J.E. Weinstein, W. Pita-Thomas, H.B. Raju, S. Iqbal, J.L. Goldberg, Nanoparticle-mediated signaling endosome localization regulates growth cone motility and neurite growth, PNAS. 108 (2011) 19042-19047. https://doi.org/10.1073/pnas.1019624108.

[103] A. Tay, A. Kunze, C. Murray, D. Di Carlo, Induction of Calcium Influx in Cortical Neural Networks by Nanomagnetic Forces, ACS Nano. 10 (2016) 2331-2341. https://doi.org/10.1021/acsnano.5b07118.

[104] A. Kunze, P. Tseng, C. Godzich, C. Murray, A. Caputo, F.E. Schweizer, D. Di Carlo, Engineering Cortical Neuron Polarity with Nanomagnets on a Chip, ACS Nano. 9 (2015) 3664-3676. https://doi.org/10.1021/nn505330w.

[105] H. Huang, S. Delikanli, H. Zeng, D.M. Ferkey, A. Pralle, Remote control of ion channels and neurons through magnetic-field heating of nanoparticles, Nature Nanotechnology. 5 (2010) 602-606. https://doi.org/10.1038/nnano.2010.125.

[106] R. Chen, G. Romero, M.G. Christiansen, A. Mohr, P. Anikeeva, Wireless magnetothermal deep brain stimulation, Science. 347 (2015) 1477-1480. https://doi.org/10.1126/science.1261821.

[107] R. Munshi, S.M. Qadri, Q. Zhang, I. Castellanos Rubio, P. del Pino, A. Pralle, Magnetothermal genetic deep brain stimulation of motor behaviors in awake, freely moving mice, ELife. 6 (2017) e27069. https://doi.org/10.7554/eLife.27069.

[108] S.A. Stanley, J.E. Gagner, S. Damanpour, M. Yoshida, J.S. Dordick, J.M. Friedman, Radio-Wave Heating of Iron Oxide Nanoparticles Can Regulate Plasma Glucose in Mice, Science. 336 (2012) 604-608. https://doi.org/10.1126/science.1216753.

[109] S. Moise, J.M. Byrne, A.J.E. Haj, N.D. Telling, The potential of magnetic hyperthermia for triggering the differentiation of cancer cells, Nanoscale. 10 (2018) 20519-20525. https://doi.org/10.1039/C8NR05946B. 
[110] M. Muthana, A.J. Kennerley, R. Hughes, E. Fagnano, J. Richardson, M. Paul, C. Murdoch, F. Wright, C. Payne, M.F. Lythgoe, N. Farrow, J. Dobson, J. Conner, J.M. Wild, C. Lewis, Directing cell therapy to anatomic target sites in vivo with magnetic resonance targeting, Nature Communications. 6 (2015) 8009. https://doi.org/10.1038/ncomms9009.

[111] J.A. Kim, J.-H. Choi, M. Kim, W.J. Rhee, B. Son, H.-K. Jung, T.H. Park, High-throughput generation of spheroids using magnetic nanoparticles for three-dimensional cell culture, Biomaterials. 34 (2013) 8555-8563. https://doi.org/10.1016/j.biomaterials.2013.07.056.

[112] A.I. Gonçalves, M.T. Rodrigues, M.E. Gomes, Tissue-engineered magnetic cell sheet patches for advanced strategies in tendon regeneration, Acta Biomater. 63 (2017) 110-122. https://doi.org/10.1016/j.actbio.2017.09.014.

[113] P. Jiang, Y. Zhang, C. Zhu, W. Zhang, Z. Mao, C. Gao, Fe3O4/BSA particles induce osteogenic differentiation of mesenchymal stem cells under static magnetic field, Acta Biomater. 46 (2016) 141-150. https://doi.org/10.1016/j.actbio.2016.09.020.

[114] R. Munshi, S.M. Qadri, A. Pralle, Transient Magnetothermal Neuronal Silencing Using the Chloride Channel Anoctamin 1 (TMEM16A), Front Neurosci. 12 (2018) 560. https://doi.org/10.3389/fnins.2018.00560.

[115] R. Massart, V. Cabuil, Synthèse en milieu alcalin de magnétite colloïdale : contrôle du rendement et de la taille des particules, J. Chim. Phys. 84 (1987) 967-973. https://doi.org/10.1051/jcp/1987840967.

[116] N. Fauconnier, J.N. Pons, J. Roger, A. Bee, Thiolation of Maghemite Nanoparticles by Dimercaptosuccinic Acid, Journal of Colloid and Interface Science. 194 (1997) 427-433. https://doi.org/10.1006/jcis.1997.5125.

[117] A. Bee, R. Massart, S. Neveu, Synthesis of very fine maghemite particles, Journal of Magnetism and Magnetic Materials. 149 (1995) 6-9. https://doi.org/10.1016/0304-8853(95)00317-7.

[118] S. Neveu-Prin, V. Cabuil, R. Massart, P. Escaffre, J. Dussaud, Encapsulation of magnetic fluids, Journal of Magnetism and Magnetic Materials. 122 (1993) 42-45. https://doi.org/10.1016/0304-8853(93)91035-6.

[119] G.B. Biddlecombe, Y.K. Gun'ko, J.M. Kelly, S.C. Pillai, J.M.D. Coey, M. Venkatesan, A.P. Douvalis, Preparation of magnetic nanoparticles and their assemblies using a new Fe(II) alkoxide precursor, J. Mater. Chem. 11 (2001) 2937-2939. https://doi.org/10.1039/B107760K.

[120] S. Richard, V. Eder, G. Caputo, C. Journé, P. Ou, J. Bolley, L. Louedec, E. Guenin, L. Motte, N. Pinna, Y. Lalatonne, USPIO size control through microwave nonaqueous sol-gel method for neoangiogenesis T2 MRI contrast agent, Nanomedicine. 11 (2016) 2769-2779. https://doi.org/10.2217/nnm-2016-0177.

[121] J. Wan, W. Cai, J. Feng, X. Meng, E. Liu, In situ decoration of carbon nanotubes with nearly monodisperse magnetite nanoparticles in liquid polyols, Journal of Materials Chemistry. 17 (2007) 1188-1192. https://doi.org/10.1039/B615527H.

[122] M. Kimata, D. Nakagawa, M. Hasegawa, Preparation of monodisperse magnetic particles by hydrolysis of iron alkoxide, Powder Technology. 132 (2003) 112-118. https://doi.org/10.1016/S0032-5910(03)00046-9.

[123] A.B. Chin, I.I. Yaacob, Synthesis and characterization of magnetic iron oxide nanoparticles via w/o microemulsion and Massart's procedure, Journal of Materials Processing Technology. 191 (2007) 235-237. https://doi.org/10.1016/j.jmatprotec.2007.03.011.

[124] G. Salazar-Alvarez, M. Muhammed, A.A. Zagorodni, Novel flow injection synthesis of iron oxide nanoparticles with narrow size distribution, Chemical Engineering Science. 61 (2006) 4625-4633. https://doi.org/10.1016/j.ces.2006.02.032.

[125] S. Basak, D.-R. Chen, P. Biswas, Electrospray of ionic precursor solutions to synthesize iron oxide nanoparticles: Modified scaling law, Chemical Engineering Science. 62 (2007) 12631268. https://doi.org/10.1016/j.ces.2006.11.029.

[126] A. Abou-Hassan, O. Sandre, V. Cabuil, P. Tabeling, Synthesis of iron oxide nanoparticles in a microfluidic device: preliminary results in a coaxial flow millichannel, Chemical Communications. 0 (2008) 1783-1785. https://doi.org/10.1039/B719550H. 
[127] A. Abou-Hassan, O. Sandre, V. Cabuil, Microfluidics in Inorganic Chemistry, Angewandte Chemie International Edition. (2018) 6268-6286. https://doi.org/10.1002/anie.200904285@10.1002/(ISSN)1521-3773.Microfluidics.

[128] L. Frenz, A. El Harrak, M. Pauly, S. Bégin-Colin, A.D. Griffiths, J.-C. Baret, Droplet-Based Microreactors for the Synthesis of Magnetic Iron Oxide Nanoparticles, Angewandte Chemie International Edition. 47 (2008) 6817-6820. https://doi.org/10.1002/anie.200801360.

[129] A. Abou-Hassan, J.-F. Dufrêche, O. Sandre, G. Mériguet, O. Bernard, V. Cabuil, Fluorescence Confocal Laser Scanning Microscopy for pH Mapping in a Coaxial Flow Microreactor: Application in the Synthesis of Superparamagnetic Nanoparticles, J. Phys. Chem. C. 113 (2009) 18097-18105. https://doi.org/10.1021/jp9069459.

[130] D. Ferraro, Y. Lin, B. Teste, D. Talbot, L. Malaquin, S. Descroix, A. Abou-Hassan, Continuous chemical operations and modifications on magnetic $\gamma$-Fe2O3 nanoparticles confined in nanoliter droplets for the assembly of fluorescent and magnetic SiO2@Y-Fe2O3, Chem. Commun. 51 (2015) 16904-16907. https://doi.org/10.1039/C5CC07044A.

[131] A.P. LaGrow, M.O. Besenhard, A. Hodzic, A. Sergides, L.K. Bogart, A. Gavriilidis, N.T.K. Thanh, Unravelling the growth mechanism of the co-precipitation of iron oxide nanoparticles with the aid of synchrotron X-Ray diffraction in solution, Nanoscale. 11 (2019) 6620-6628. https://doi.org/10.1039/C9NR00531E.

[132] R. Massart, Preparation of aqueous magnetic liquids in alkaline and acidic media, IEEE Transactions on Magnetics. 17 (1981) 1247-1248. https://doi.org/10.1109/TMAG.1981.1061188.

[133] N. Fauconnier, A. Bee, J. Roger, J.N. Pons, Adsorption of gluconic and citric acids on maghemite particles in aqueous medium, in: C. Solans, M.R. Infante, M.J. García-Celma (Eds.), Trends in Colloid and Interface Science X, Steinkopff, Darmstadt, 1996: pp. 212-216. https://doi.org/10.1007/BFb0115782.

[134] N. Fauconnier, A. Bée, J. Roger, J.N. Pons, Synthesis of aqueous magnetic liquids by surface complexation of maghemite nanoparticles, Journal of Molecular Liquids. 83 (1999) 233-242. https://doi.org/10.1016/\$0167-7322(99)00088-4.

[135] N. Fauconnier, J.N. Pons, J. Roger, A. Bee, Thiolation of Maghemite Nanoparticles by Dimercaptosuccinic Acid, Journal of Colloid and Interface Science. 194 (1997) 427-433. https://doi.org/10.1006/jcis.1997.5125.

[136] J. Roger, J.N. Pons, R. Massart, A. Halbreich, J.C. Bacri, Some biomedical applications of ferrofluids, Eur. Phys. J. AP. 5 (1999) 321-325. https://doi.org/10.1051/epjap:1999144.

[137] B. Denizot, G. Tanguy, F. Hindre, E. Rump, J. Jacques Le Jeune, P. Jallet, Phosphorylcholine Coating of Iron Oxide Nanoparticles, Journal of Colloid and Interface Science. 209 (1999) 6671. https://doi.org/10.1006/jcis.1998.5850.

[138] N. Giamblanco, G. Marletta, A. Graillot, N. Bia, C. Loubat, J.-F. Berret, Serum Protein-Resistant Behavior of Multisite-Bound Poly(ethylene glycol) Chains on Iron Oxide Surfaces, ACS Omega. 2 (2017) 1309-1320. https://doi.org/10.1021/acsomega.7b00007.

[139] T. Coccini, U. De Simone, M. Roccio, S. Croce, E. Lenta, M. Zecca, A. Spinillo, M.A. Avanzini, In vitro toxicity screening of magnetite nanoparticles by applying mesenchymal stem cells derived from human umbilical cord lining, Journal of Applied Toxicology. 0 (2019). https://doi.org/10.1002/jat.3819.

[140] S.K. Avugadda, M.E. Materia, R. Nigmatullin, D. Cabrera, R. Marotta, T.F. Cabada, E. Marcello, S. Nitti, E.J. Artés-Ibañez, P. Basnett, C. Wilhelm, F.J. Teran, I. Roy, T. Pellegrino, EsteraseCleavable 2D Assemblies of Magnetic Iron Oxide Nanocubes: Exploiting Enzymatic Polymer Disassembling To Improve Magnetic Hyperthermia Heat Losses, Chem. Mater. 31 (2019) 5450-5463. https://doi.org/10.1021/acs.chemmater.9b00728.

[141] C. Feldmann, H.-O. Jungk, Polyol-Mediated Preparation of Nanoscale Oxide Particles, Angewandte Chemie International Edition. 40 (2001) 359-362. https://doi.org/10.1002/15213773(20010119)40:2<359::AID-ANIE359>3.0.CO;2-B. 
[142] D. Jézéquel, J. Guenot, N. Jouini, F. Fiévet, Submicrometer zinc oxide particles: Elaboration in polyol medium and morphological characteristics, Journal of Materials Research. 10 (1995) 77-83. https://doi.org/10.1557/JMR.1995.0077.

[143] M. Wetegrove, K. Witte, W. Bodnar, D.-E. Pfahl, A. Springer, N. Schell, F. Westphal, E. Burkel, Formation of maghemite nanostructures in polyol: tuning the particle size via the precursor stoichiometry, CrystEngComm. 21 (2019) 1956-1966. https://doi.org/10.1039/C8CE02115E.

[144] P. Hugounenq, M. Levy, D. Alloyeau, L. Lartigue, E. Dubois, V. Cabuil, C. Ricolleau, S. Roux, C. Wilhelm, F. Gazeau, R. Bazzi, Iron Oxide Monocrystalline Nanoflowers for Highly Efficient Magnetic Hyperthermia, J. Phys. Chem. C. 116 (2012) 15702-15712. https://doi.org/10.1021/jp3025478.

[145] V.K. Tzitzios, D. Petridis, I. Zafiropoulou, G. Hadjipanayis, D. Niarchos, Synthesis and characterization of L10 FePt nanoparticles from Pt-Fe304 core-shell nanoparticles, Journal of Magnetism and Magnetic Materials. 294 (2005) e95-e98. https://doi.org/10.1016/j.jmmm.2005.03.061.

[146] G.M. Chow, L.K. Kurihara, K.M. Kemner, P.E. Schoen, W.T. Elam, A. Ervin, S. Keller, Y.D. Zhang, J. Budnick, T. Ambrose, Structural, morphological, and magnetic study of nanocrystalline cobalt-copper powders synthesized by the polyol process, Journal of Materials Research. 10 (1995) 1546-1554. https://doi.org/10.1557/JMR.1995.1546.

[147] G. Viau, F. Ravel, O. Acher, F. Fiévet-Vincent, F. Fiévet, Preparation and microwave characterization of spherical and monodisperse Co20Ni80 particles, Journal of Applied Physics. 76 (1994) 6570-6572. https://doi.org/10.1063/1.358473.

[148] G. Viau, F. Ravel, O. Acher, F. Fiévet-Vincent, F. Fiévet, Preparation and microwave characterization of spherical and monodisperse Co?Ni particles, Journal of Magnetism and Magnetic Materials. 140-144 (1995) 377-378. https://doi.org/10.1016/0304-8853(94)007926.

[149] G. Viau, F. Fiévet-Vincent, F. Fiévet, Nucleation and growth of bimetallic CoNi and FeNi monodisperse particles prepared in polyols, Solid State lonics. 84 (1996) 259-270. https://doi.org/10.1016/0167-2738(96)00005-7.

[150] C. Feldmann, Preparation of Nanoscale Pigment Particles, Advanced Materials. 13 (2001) 1301-1303. https://doi.org/10.1002/1521-4095(200109)13:17<1301::AIDADMA1301>3.0.CO;2-6.

[151] W. Cai, J. Wan, Facile synthesis of superparamagnetic magnetite nanoparticles in liquid polyols, Journal of Colloid and Interface Science. 305 (2007) 366-370. https://doi.org/10.1016/j.jcis.2006.10.023.

[152] D. Caruntu, G. Caruntu, Y. Chen, C.J. O'Connor, G. Goloverda, V.L. Kolesnichenko, Synthesis of Variable-Sized Nanocrystals of Fe304 with High Surface Reactivity, Chem. Mater. 16 (2004) 5527-5534. https://doi.org/10.1021/cm0487977.

[153] C. Cheng, F. Xu, H. Gu, Facile synthesis and morphology evolution of magnetic iron oxide nanoparticles in different polyol processes, New Journal of Chemistry. 35 (2011) 1072-1079. https://doi.org/10.1039/CONJ00986E.

[154] S.J.H. Soenen, N. Nuytten, S.F. De Meyer, S.C. De Smedt, M. De Cuyper, High intracellular iron oxide nanoparticle concentrations affect cellular cytoskeleton and focal adhesion kinasemediated signaling, Small. 6 (2010) 832-842. https://doi.org/10.1002/smll.200902084.

[155] S.J.H. Soenen, U. Himmelreich, N. Nuytten, M. De Cuyper, Cytotoxic effects of iron oxide nanoparticles and implications for safety in cell labelling, Biomaterials. 32 (2011) 195-205. https://doi.org/10.1016/j.biomaterials.2010.08.075.

[156] B. Laffon, N. Fernández-Bertólez, C. Costa, F. Brandão, J.P. Teixeira, E. Pásaro, V. Valdiglesias, Cellular and Molecular Toxicity of Iron Oxide Nanoparticles, in: Q. Saquib, M. Faisal, A.A. AlKhedhairy, A.A. Alatar (Eds.), Cellular and Molecular Toxicology of Nanoparticles, Springer International Publishing, Cham, 2018: pp. 199-213. https://doi.org/10.1007/978-3-31972041-8_12. 
[157] V. Valdiglesias, G. Kiliç, C. Costa, N. Fernández-Bertólez, E. Pásaro, J.P. Teixeira, B. Laffon, Effects of iron oxide nanoparticles: cytotoxicity, genotoxicity, developmental toxicity, and neurotoxicity, Environ. Mol. Mutagen. 56 (2015) 125-148. https://doi.org/10.1002/em.21909.

[158] V. Valdiglesias, N. Fernández-Bertólez, G. Kiliç, C. Costa, S. Costa, S. Fraga, M.J. Bessa, E. Pásaro, J.P. Teixeira, B. Laffon, Are iron oxide nanoparticles safe? Current knowledge and future perspectives, Journal of Trace Elements in Medicine and Biology. 38 (2016) 53-63. https://doi.org/10.1016/j.jtemb.2016.03.017.

[159] C. Wilhelm, F. Gazeau, Universal cell labelling with anionic magnetic nanoparticles, Biomaterials. 29 (2008) 3161-3174. https://doi.org/10.1016/j.biomaterials.2008.04.016.

[160] R. Hachani, M.A. Birchall, M.W. Lowdell, G. Kasparis, L.D. Tung, B.B. Manshian, S.J. Soenen, W. Gsell, U. Himmelreich, C.A. Gharagouzloo, S. Sridhar, N.T.K. Thanh, Assessing cell-nanoparticle interactions by high content imaging of biocompatible iron oxide nanoparticles as potential contrast agents for magnetic resonance imaging, Sci Rep. 7 (2017) 7850. https://doi.org/10.1038/s41598-017-08092-w.

[161] L. Lartigue, C. Wilhelm, J. Servais, C. Factor, A. Dencausse, J.-C. Bacri, N. Luciani, F. Gazeau, Nanomagnetic Sensing of Blood Plasma Protein Interactions with Iron Oxide Nanoparticles: Impact on Macrophage Uptake, ACS Nano. 6 (2012) 2665-2678. https://doi.org/10.1021/nn300060u.

[162] A. Ruiz, A. Alpízar, L. Beola, C. Rubio, H. Gavilán, M. Marciello, I. Rodríguez-Ramiro, S. Ciordia, C.J. Morris, M.D.P. Morales, Understanding the Influence of a Bifunctional Polyethylene Glycol Derivative in Protein Corona Formation around Iron Oxide Nanoparticles, Materials (Basel). 12 (2019). https://doi.org/10.3390/ma12142218.

[163] R.M. Patil, N.D. Thorat, P.B. Shete, P.A. Bedge, S. Gavde, M.G. Joshi, S.A.M. Tofail, R.A. Bohara, Comprehensive cytotoxicity studies of superparamagnetic iron oxide nanoparticles, Biochemistry and Biophysics Reports. 13 (2018) 63-72. https://doi.org/10.1016/j.bbrep.2017.12.002.

[164] Q. Feng, Y. Liu, J. Huang, K. Chen, J. Huang, K. Xiao, Uptake, distribution, clearance, and toxicity of iron oxide nanoparticles with different sizes and coatings, Scientific Reports. 8 (2018) 2082. https://doi.org/10.1038/s41598-018-19628-z.

[165] W. Xie, Z. Guo, F. Gao, Q. Gao, D. Wang, B. Liaw, Q. Cai, X. Sun, X. Wang, L. Zhao, Shape-, sizeand structure-controlled synthesis and biocompatibility of iron oxide nanoparticles for magnetic theranostics, Theranostics. 8 (2018) 3284-3307. https://doi.org/10.7150/thno.25220.

[166] N. Hoshyar, S. Gray, H. Han, G. Bao, The effect of nanoparticle size on in vivo pharmacokinetics and cellular interaction, Nanomedicine (Lond). 11 (2016) 673-692. https://doi.org/10.2217/nnm.16.5.

[167] H. Arami, A. Khandhar, D. Liggitt, K.M. Krishnan, In vivo delivery, pharmacokinetics, biodistribution and toxicity of iron oxide nanoparticles, Chem Soc Rev. 44 (2015) 8576-8607. https://doi.org/10.1039/c5cs00541h.

[168] X. Sun, M. Gamal, P. Nold, A. Said, I. Chakraborty, B. Pelaz, F. Schmied, K. von Pückler, J. Figiel, Y. Zhao, C. Brendel, M. Hassan, W.J. Parak, N. Feliu, Tracking stem cells and macrophages with gold and iron oxide nanoparticles - The choice of the best suited particles, Applied Materials Today. 15 (2019) 267-279. https://doi.org/10.1016/j.apmt.2018.12.006.

[169] B.B. Manshian, D.F. Moyano, N. Corthout, S. Munck, U. Himmelreich, V.M. Rotello, S.J. Soenen, High-content imaging and gene expression analysis to study cell-nanomaterial interactions: the effect of surface hydrophobicity, Biomaterials. 35 (2014) 9941-9950. https://doi.org/10.1016/j.biomaterials.2014.08.031.

[170] S.C. Hong, J.H. Lee, J. Lee, H.Y. Kim, J.Y. Park, J. Cho, J. Lee, D.-W. Han, Subtle cytotoxicity and genotoxicity differences in superparamagnetic iron oxide nanoparticles coated with various functional groups, Int J Nanomedicine. 6 (2011) 3219-3231. https://doi.org/10.2147/IJN.S26355. 
[171] A. Villanueva, M. Cañete, A.G. Roca, M. Calero, S. Veintemillas-Verdaguer, C.J. Serna, M. del P. Morales, R. Miranda, The influence of surface functionalization on the enhanced internalization of magnetic nanoparticles in cancer cells, Nanotechnology. 20 (2009) 115103. https://doi.org/10.1088/0957-4484/20/11/115103.

[172] G. Zeng, G. Wang, F. Guan, K. Chang, H. Jiao, W. Gao, S. Xi, B. Yang, Human amniotic membrane-derived mesenchymal stem cells labeled with superparamagnetic iron oxide nanoparticles: the effect on neuron-like differentiation in vitro, Mol. Cell. Biochem. 357 (2011) 331-341. https://doi.org/10.1007/s11010-011-0904-4.

[173] A. Van de Walle, W. Faissal, C. Wilhelm, N. Luciani, Role of growth factors and oxygen to limit hypertrophy and impact of high magnetic nanoparticles dose during stem cell chondrogenesis, Comput Struct Biotechnol J. 16 (2018) 532-542. https://doi.org/10.1016/j.csbj.2018.10.014.

[174] S. Ashraf, A. Taylor, J. Sharkey, M. Barrow, P. Murray, B. Wilm, H. Poptani, M.J. Rosseinsky, D.J. Adams, R. Lévy, In vivo fate of free and encapsulated iron oxide nanoparticles after injection of labelled stem cells, Nanoscale Adv. 1 (2019) 367-377. https://doi.org/10.1039/C8NA00098K.

[175] A. Shah, M.A. Dobrovolskaia, Immunological Effects of Iron Oxide Nanoparticles and Ironbased Complex Drug Formulations: Therapeutic Benefits, Toxicity, Mechanistic Insights, and Translational Considerations, Nanomedicine : Nanotechnology, Biology, and Medicine. 14 (2018) 977. https://doi.org/10.1016/j.nano.2018.01.014.

[176] A.P. Sangnier, A.V. de Walle, A. Curcio, R.L. Borgne, L. Motte, Y. Lalatonne, C. Wilhelm, Impact of magnetic nanoparticle surface coating on their long-term intracellular biodegradation in stem cells, Nanoscale. (2019). https://doi.org/10.1039/C9NR05624F.

[177] A. Van de Walle, A. Plan Sangnier, A. Abou-Hassan, A. Curcio, M. Hémadi, N. Menguy, Y. Lalatonne, N. Luciani, C. Wilhelm, Biosynthesis of magnetic nanoparticles from nanodegradation products revealed in human stem cells, Proc. Natl. Acad. Sci. U.S.A. 116 (2019) 4044-4053. https://doi.org/10.1073/pnas.1816792116.

[178] H. Negi, S. Takeuchi, N. Kamei, S. Yanada, N. Adachi, M. Ochi, Safety and Quality of Magnetically Labeled Human Mesenchymal Stem Cells for Cartilage Repair, Tissue Eng Part C Methods. (2019). https://doi.org/10.1089/ten.TEC.2019.0001.

[179] Y.-K. Chang, Y.-P. Liu, J.H. Ho, S.-C. Hsu, O.K. Lee, Amine-surface-modified superparamagnetic iron oxide nanoparticles interfere with differentiation of human mesenchymal stem cells, J. Orthop. Res. 30 (2012) 1499-1506. https://doi.org/10.1002/jor.22088.

[180] Y.-C. Chen, J.-K. Hsiao, H.-M. Liu, I.-Y. Lai, M. Yao, S.-C. Hsu, B.-S. Ko, Y.-C. Chen, C.-S. Yang, D.M. Huang, The inhibitory effect of superparamagnetic iron oxide nanoparticle (Ferucarbotran) on osteogenic differentiation and its signaling mechanism in human mesenchymal stem cells, Toxicol. Appl. Pharmacol. 245 (2010) 272-279. https://doi.org/10.1016/j.taap.2010.03.011.

[181] D.-M. Huang, J.-K. Hsiao, Y.-C. Chen, L.-Y. Chien, M. Yao, Y.-K. Chen, B.-S. Ko, S.-C. Hsu, L.-A. Tai, H.-Y. Cheng, S.-W. Wang, C.-S. Yang, Y.-C. Chen, The promotion of human mesenchymal stem cell proliferation by superparamagnetic iron oxide nanoparticles, Biomaterials. 30 (2009) 3645-3651. https://doi.org/10.1016/j.biomaterials.2009.03.032.

[182] E. Roeder, C. Henrionnet, J.C. Goebel, N. Gambier, O. Beuf, D. Grenier, B. Chen, P.-A. Vuissoz, P. Gillet, A. Pinzano, Dose-response of superparamagnetic iron oxide labeling on mesenchymal stem cells chondrogenic differentiation: a multi-scale in vitro study, PLoS ONE. 9 (2014) e98451. https://doi.org/10.1371/journal.pone.0098451.

[183] L. Kostura, D.L. Kraitchman, A.M. Mackay, M.F. Pittenger, J.W.M. Bulte, Feridex labeling of mesenchymal stem cells inhibits chondrogenesis but not adipogenesis or osteogenesis, NMR Biomed. 17 (2004) 513-517. https://doi.org/10.1002/nbm.925.

[184] D. Fayol, N. Luciani, L. Lartigue, F. Gazeau, C. Wilhelm, Managing magnetic nanoparticle aggregation and cellular uptake: a precondition for efficient stem-cell differentiation and MRI tracking, Adv Healthc Mater. 2 (2013) 313-325. https://doi.org/10.1002/adhm.201200294.

[185] K. Andreas, R. Georgieva, M. Ladwig, S. Mueller, M. Notter, M. Sittinger, J. Ringe, Highly efficient magnetic stem cell labeling with citrate-coated superparamagnetic iron oxide 
nanoparticles for MRI tracking, Biomaterials. 33 (2012) 4515-4525.

https://doi.org/10.1016/j.biomaterials.2012.02.064.

[186] H. Jülke, C. Veit, I. Ribitsch, W. Brehm, E. Ludewig, U. Delling, Comparative Labeling of Equine and Ovine Multipotent Stromal Cells With Superparamagnetic Iron Oxide Particles for Magnetic Resonance Imaging In Vitro, Cell Transplant. 24 (2015) 1111-1125. https://doi.org/10.3727/096368913X675737.

[187] T.D. Henning, E.J. Sutton, A. Kim, D. Golovko, A. Horvai, L. Ackerman, B. Sennino, D. McDonald, J. Lotz, H.E. Daldrup-Link, The influence of ferucarbotran on the chondrogenesis of human mesenchymal stem cells, Contrast Media Mol Imaging. 4 (2009) 165-173. https://doi.org/10.1002/cmmi.276.

[188] N.D. Maggio, E. Martella, S. Meikle, M. Columbaro, E. Lucarelli, M. Santin, A. Banfi, Rapid and efficient magnetization of mesenchymal stem cells by dendrimer-functionalized magnetic nanoparticles, Nanomedicine (Lond). 11 (2016) 1519-1534. https://doi.org/10.2217/nnm2016-0085.

[189] Y. Xia, J. Sun, L. Zhao, F. Zhang, X.-J. Liang, Y. Guo, M.D. Weir, M.A. Reynolds, N. Gu, H.H.K. Xu, Magnetic field and nano-scaffolds with stem cells to enhance bone regeneration, Biomaterials. 183 (2018) 151-170. https://doi.org/10.1016/j.biomaterials.2018.08.040.

[190] Q. Wang, B. Chen, M. Cao, J. Sun, H. Wu, P. Zhao, J. Xing, Y. Yang, X. Zhang, M. Ji, N. Gu, Response of MAPK pathway to iron oxide nanoparticles in vitro treatment promotes osteogenic differentiation of hBMSCs, Biomaterials. 86 (2016) 11-20. https://doi.org/10.1016/j.biomaterials.2016.02.004.

[191] Q. Wang, B. Chen, F. Ma, S. Lin, M. Cao, Y. Li, N. Gu, Magnetic iron oxide nanoparticles accelerate osteogenic differentiation of mesenchymal stem cells via modulation of long noncoding RNA INZEB2, Nano Res. 10 (2017) 626-642. https://doi.org/10.1007/s12274-0161322-4.

[192] E. Farrell, P. Wielopolski, P. Pavljasevic, S. van Tiel, H. Jahr, J. Verhaar, H. Weinans, G. Krestin, F.J. O'Brien, G. van Osch, M. Bernsen, Effects of iron oxide incorporation for long term cell tracking on MSC differentiation in vitro and in vivo, Biochem. Biophys. Res. Commun. 369 (2008) 1076-1081. https://doi.org/10.1016/j.bbrc.2008.02.159.

[193] A. Crabbe, C. Vandeputte, T. Dresselaers, A.A. Sacido, J.M.G. Verdugo, J. Eyckmans, F.P. Luyten, K. Van Laere, C.M. Verfaillie, U. Himmelreich, Effects of MRI contrast agents on the stem cell phenotype, Cell Transplant. 19 (2010) 919-936. https://doi.org/10.3727/096368910X494623.

[194] L. Wang, J. Deng, J. Wang, B. Xiang, T. Yang, M. Gruwel, T. Kashour, B. Tomanek, R. Summer, D. Freed, D.S. Jassal, G. Dai, M. Glogowski, R. Deslauriers, R.C. Arora, G. Tian, Superparamagnetic iron oxide does not affect the viability and function of adipose-derived stem cells, and superparamagnetic iron oxide-enhanced magnetic resonance imaging identifies viable cells, Magn Reson Imaging. 27 (2009) 108-119. https://doi.org/10.1016/j.mri.2008.05.013.

[195] L.H.A. Silva, J.R. da Silva, G.A. Ferreira, R.C. Silva, E.C.D. Lima, R.B. Azevedo, D.M. Oliveira, Labeling mesenchymal cells with DMSA-coated gold and iron oxide nanoparticles: assessment of biocompatibility and potential applications, Journal of Nanobiotechnology. 14 (2016) 59. https://doi.org/10.1186/s12951-016-0213-x.

[196] F. Schulze, A. Dienelt, S. Geissler, P. Zaslansky, J. Schoon, K. Henzler, P. Guttmann, A. Gramoun, L.A. Crowe, L. Maurizi, J.-P. Vallée, H. Hofmann, G.N. Duda, A. Ode, Amino-polyvinyl alcohol coated superparamagnetic iron oxide nanoparticles are suitable for monitoring of human mesenchymal stromal cells in vivo, Small. 10 (2014) 4340-4351. https://doi.org/10.1002/smll.201400707.

[197] J.-H. Sun, Y.-L. Zhang, S.-P. Qian, X.-B. Yu, H.-Y. Xie, L. Zhou, S.-S. Zheng, Assessment of biological characteristics of mesenchymal stem cells labeled iron oxide particles in vitro, Mol Med Rep. 5 (2012) 317-320. https://doi.org/10.3892/mmr.2011.637. 
[198] S. Saha, X.B. Yang, S. Tanner, S. Curran, D. Wood, J. Kirkham, The effects of iron oxide incorporation on the chondrogenic potential of three human cell types, J Tissue Eng Regen Med. 7 (2013) 461-469. https://doi.org/10.1002/term.544.

[199] A.S. Arbab, G.T. Yocum, A.M. Rad, A.Y. Khakoo, V. Fellowes, E.J. Read, J.A. Frank, Labeling of cells with ferumoxides-protamine sulfate complexes does not inhibit function or differentiation capacity of hematopoietic or mesenchymal stem cells, NMR Biomed. 18 (2005) 553-559. https://doi.org/10.1002/nbm.991.

[200] C.-Y. Yang, J.-K. Hsiao, M.-F. Tai, S.-T. Chen, H.-Y. Cheng, J.-L. Wang, H.-M. Liu, Direct labeling of hMSC with SPIO: the long-term influence on toxicity, chondrogenic differentiation capacity, and intracellular distribution, Mol Imaging Biol. 13 (2011) 443-451. https://doi.org/10.1007/s11307-010-0360-7.

[201] K.-W. Au, S.-Y. Liao, Y.-K. Lee, W.-H. Lai, K.-M. Ng, Y.-C. Chan, M.-C. Yip, C.-Y. Ho, E.X. Wu, R.A. $\mathrm{Li}, \mathrm{C}$.-W. Siu, H.-F. Tse, Effects of iron oxide nanoparticles on cardiac differentiation of embryonic stem cells, Biochem. Biophys. Res. Commun. 379 (2009) 898-903. https://doi.org/10.1016/j.bbrc.2008.12.160.

[202] N. Fahy, M. Alini, M.J. Stoddart, Mechanical stimulation of mesenchymal stem cells: Implications for cartilage tissue engineering, Journal of Orthopaedic Research. 36 (2018) 5263. https://doi.org/10.1002/jor.23670.

[203] A.J. Steward, D.J. Kelly, Mechanical regulation of mesenchymal stem cell differentiation, J Anat. 227 (2015) 717-731. https://doi.org/10.1111/joa.12243.

[204] T. Zhang, F. Wen, Y. Wu, G.S.H. Goh, Z. Ge, L.P. Tan, J.H.P. Hui, Z. Yang, Cross-talk between TGF-beta/SMAD and integrin signaling pathways in regulating hypertrophy of mesenchymal stem cell chondrogenesis under deferral dynamic compression, Biomaterials. 38 (2015) 72-85. https://doi.org/10.1016/j.biomaterials.2014.10.010.

[205] B. Son, H.D. Kim, M. Kim, J.A. Kim, J. Lee, H. Shin, N.S. Hwang, T.H. Park, Physical StimuliInduced Chondrogenic Differentiation of Mesenchymal Stem Cells Using Magnetic Nanoparticles, Adv Healthc Mater. 4 (2015) 1339-1347. https://doi.org/10.1002/adhm.201400835.

[206] J. Lima, A.I. Gonçalves, M.T. Rodrigues, R.L. Reis, M.E. Gomes, The effect of magnetic stimulation on the osteogenic and chondrogenic differentiation of human stem cells derived from the adipose tissue (hASCs), Journal of Magnetism and Magnetic Materials. 393 (2015) 526-536. https://doi.org/10.1016/j.jmmm.2015.05.087.

[207] X. Chen, Z. Qin, J. Zhao, X. Yan, J. Ye, E. Ren, J. Wang, X. Yang, S. Heng, L. Zheng, G. Liu, Pulsed Magnetic Field Stimuli Can Promote Chondrogenic Differentiation of Superparamagnetic Iron Oxide Nanoparticles-Labeled Mesenchymal Stem Cells in Rats, J Biomed Nanotechnol. 14 (2018) 2135-2145. https://doi.org/10.1166/jbn.2018.2644.

[208] Y. Arfat, W.-Z. Xiao, S. Iftikhar, F. Zhao, D.-J. Li, Y.-L. Sun, G. Zhang, P. Shang, A.-R. Qian, Physiological Effects of Microgravity on Bone Cells, Calcif Tissue Int. 94 (2014) 569-579. https://doi.org/10.1007/s00223-014-9851-x.

[209] C. Cao, L. Li, H. Li, X. He, G. Wu, X. Yu, Cyclic biaxial tensile strain promotes bone marrowderived mesenchymal stem cells to differentiate into cardiomyocyte-like cells by miRNA-27a, The International Journal of Biochemistry \& Cell Biology. 99 (2018) 125-132. https://doi.org/10.1016/j.biocel.2018.04.004.

[210] J.R. Henstock, M. Rotherham, H. Rashidi, K.M. Shakesheff, A.J. El Haj, Remotely Activated Mechanotransduction via Magnetic Nanoparticles Promotes Mineralization Synergistically With Bone Morphogenetic Protein 2: Applications for Injectable Cell Therapy, Stem Cells Transl Med. 3 (2014) 1363-1374. https://doi.org/10.5966/sctm.2014-0017.

[211] M. Rotherham, J.R. Henstock, O. Qutachi, A.J. El Haj, Remote regulation of magnetic particle targeted Wnt signaling for bone tissue engineering, Nanomedicine: Nanotechnology, Biology and Medicine. 14 (2018) 173-184. https://doi.org/10.1016/j.nano.2017.09.008. 
[212] J.M. Kanczler, H.S. Sura, J. Magnay, D. Green, R.O.C. Oreffo, J.P. Dobson, A.J. El Haj, Controlled differentiation of human bone marrow stromal cells using magnetic nanoparticle technology, Tissue Eng Part A. 16 (2010) 3241-3250. https://doi.org/10.1089/ten.TEA.2009.0638.

[213] H. Kang, D.S.H. Wong, X. Yan, H.J. Jung, S. Kim, S. Lin, K. Wei, G. Li, V.P. Dravid, L. Bian, Remote Control of Multimodal Nanoscale Ligand Oscillations Regulates Stem Cell Adhesion and Differentiation, ACS Nano. 11 (2017) 9636-9649. https://doi.org/10.1021/acsnano.7b02857.

[214] R. Schäfer, R. Bantleon, R. Kehlbach, G. Siegel, J. Wiskirchen, H. Wolburg, T. Kluba, F. Eibofner, H. Northoff, C.D. Claussen, H.-P. Schlemmer, Functional investigations on human mesenchymal stem cells exposed to magnetic fields and labeled with clinically approved iron nanoparticles, BMC Cell Biol. 11 (2010) 22. https://doi.org/10.1186/1471-2121-11-22.

[215] T. Norizadeh-Abbariki, O. Mashinchian, M.A. Shokrgozar, N. Haghighipour, T. Sen, M. Mahmoudi, Superparamagnetic Nanoparticles Direct Differentiation of Embryonic Stem Cells Into Skeletal Muscle Cells, Journal of Biomaterials and Tissue Engineering. 4 (2014) 579-585. https://doi.org/10.1166/jbt.2014.1205.

[216] B.T.T. Pham, E.K. Colvin, N.T.H. Pham, B.J. Kim, E.S. Fuller, E.A. Moon, R. Barbey, S. Yuen, B.H. Rickman, N.S. Bryce, S. Bickley, M. Tanudji, S.K. Jones, V.M. Howell, B.S. Hawkett, Biodistribution and Clearance of Stable Superparamagnetic Maghemite Iron Oxide Nanoparticles in Mice Following Intraperitoneal Administration, Int J Mol Sci. 19 (2018). https://doi.org/10.3390/ijms19010205.

[217] J. Kolosnjaj-Tabi, L. Lartigue, Y. Javed, N. Luciani, T. Pellegrino, C. Wilhelm, D. Alloyeau, F. Gazeau, Biotransformations of magnetic nanoparticles in the body, Nano Today. 11 (2016) 280-284. https://doi.org/10.1016/j.nantod.2015.10.001.

[218] D. Bargheer, A. Giemsa, B. Freund, M. Heine, C. Waurisch, G.M. Stachowski, S.G. Hickey, A. Eychmüller, J. Heeren, P. Nielsen, The distribution and degradation of radiolabeled superparamagnetic iron oxide nanoparticles and quantum dots in mice, Beilstein J Nanotechnol. 6 (2015) 111-123. https://doi.org/10.3762/bjnano.6.11.

[219] B. Freund, U.I. Tromsdorf, O.T. Bruns, M. Heine, A. Giemsa, A. Bartelt, S.C. Salmen, N. Raabe, J. Heeren, H. Ittrich, R. Reimer, H. Hohenberg, U. Schumacher, H. Weller, P. Nielsen, A simple and widely applicable method to 59Fe-radiolabel monodisperse superparamagnetic iron oxide nanoparticles for in vivo quantification studies, ACS Nano. 6 (2012) 7318-7325. https://doi.org/10.1021/nn3024267.

[220] S.P. Singh, M.F. Rahman, U.S.N. Murty, M. Mahboob, P. Grover, Comparative study of genotoxicity and tissue distribution of nano and micron sized iron oxide in rats after acute oral treatment, Toxicol. Appl. Pharmacol. 266 (2013) 56-66. https://doi.org/10.1016/j.taap.2012.10.016.

[221] M. Levy, N. Luciani, D. Alloyeau, D. Elgrabli, V. Deveaux, C. Pechoux, S. Chat, G. Wang, N. Vats, F. Gendron, C. Factor, S. Lotersztajn, A. Luciani, C. Wilhelm, F. Gazeau, Long term in vivo biotransformation of iron oxide nanoparticles, Biomaterials. 32 (2011) 3988-3999. https://doi.org/10.1016/j.biomaterials.2011.02.031.

[222] K. Briley-Saebo, A. Bjørnerud, D. Grant, H. Ahlstrom, T. Berg, G.M. Kindberg, Hepatic cellular distribution and degradation of iron oxide nanoparticles following single intravenous injection in rats: implications for magnetic resonance imaging, Cell Tissue Res. 316 (2004) 315-323. https://doi.org/10.1007/s00441-004-0884-8.

[223] L. Gu, R.H. Fang, M.J. Sailor, J.-H. Park, In Vivo Clearance and Toxicity of Monodisperse Iron Oxide Nanocrystals, ACS Nano. 6 (2012) 4947-4954. https://doi.org/10.1021/nn300456z.

[224] E. Gammella, P. Buratti, G. Cairo, S. Recalcati, Macrophages: central regulators of iron balance, Metallomics. 6 (2014) 1336-1345. https://doi.org/10.1039/C4MT00104D.

[225] M. Lévy, F. Lagarde, V.-A. Maraloiu, M.-G. Blanchin, F. Gendron, C. Wilhelm, F. Gazeau, Degradability of superparamagnetic nanoparticles in a model of intracellular environment: follow-up of magnetic, structural and chemical properties, Nanotechnology. 21 (2010) 395103. https://doi.org/10.1088/0957-4484/21/39/395103. 
[226] N. Feliu, D. Docter, M. Heine, P. Del Pino, S. Ashraf, J. Kolosnjaj-Tabi, P. Macchiarini, P. Nielsen, D. Alloyeau, F. Gazeau, R.H. Stauber, W.J. Parak, In vivo degeneration and the fate of inorganic nanoparticles, Chem Soc Rev. 45 (2016) 2440-2457. https://doi.org/10.1039/c5cs00699f.

[227] A.S. Arbab, L.B. Wilson, P. Ashari, E.K. Jordan, B.K. Lewis, J.A. Frank, A model of lysosomal metabolism of dextran coated superparamagnetic iron oxide (SPIO) nanoparticles: implications for cellular magnetic resonance imaging, NMR Biomed. 18 (2005) 383-389. https://doi.org/10.1002/nbm.970.

[228] C. Wilhelm, F. Gazeau, J.-C. Bacri, Magnetophoresis and ferromagnetic resonance of magnetically labeled cells, Eur. Biophys. J. 31 (2002) 118-125. https://doi.org/10.1007/s00249-001-0200-4.

[229] A. Van de Walle, A. Fromain, A.P. Sangnier, A. Curcio, L. Lenglet, L. Motte, Y. Lalatonne, C. Wilhelm, Real-time in situ magnetic measurement of the intracellular biodegradation of iron oxide nanoparticles in a stem cell-spheroid tissue model, Nano Res. 13 (2020) 467-476. https://doi.org/10.1007/s12274-020-2631-1.

[230] R. Weissleder, D.D. Stark, B.L. Engelstad, B.R. Bacon, C.C. Compton, D.L. White, P. Jacobs, J. Lewis, Superparamagnetic iron oxide: pharmacokinetics and toxicity, AJR Am J Roentgenol. 152 (1989) 167-173. https://doi.org/10.2214/ajr.152.1.167.

[231] Z. Yarjanli, K. Ghaedi, A. Esmaeili, S. Rahgozar, A. Zarrabi, Iron oxide nanoparticles may damage to the neural tissue through iron accumulation, oxidative stress, and protein aggregation, BMC Neuroscience. 18 (2017) 51. https://doi.org/10.1186/s12868-017-0369-9.

[232] S.J.H. Soenen, U. Himmelreich, N. Nuytten, T.R. Pisanic, A. Ferrari, M. De Cuyper, Intracellular nanoparticle coating stability determines nanoparticle diagnostics efficacy and cell functionality, Small. 6 (2010) 2136-2145. https://doi.org/10.1002/smll.201000763.

[233] V. Garcés, A. Rodríguez-Nogales, A. González, N. Gálvez, M.E. Rodríguez-Cabezas, M.L. GarcíaMartin, L. Gutiérrez, D. Rondón, M. Olivares, J. Gálvez, J.M. Dominguez-Vera, Bacteria-Carried Iron Oxide Nanoparticles for Treatment of Anemia, Bioconjugate Chem. 29 (2018) 1785-1791. https://doi.org/10.1021/acs.bioconjchem.8b00245.

[234] S.E. Kim, L. Zhang, K. Ma, M. Riegman, F. Chen, I. Ingold, M. Conrad, M.Z. Turker, M. Gao, X. Jiang, S. Monette, M. Pauliah, M. Gonen, P. Zanzonico, T. Quinn, U. Wiesner, M.S. Bradbury, M. Overholtzer, Ultrasmall nanoparticles induce ferroptosis in nutrient-deprived cancer cells and suppress tumour growth, Nat Nanotechnol. 11 (2016) 977-985. https://doi.org/10.1038/nnano.2016.164.

[235] N. Sukhbaatar, T. Weichhart, Iron Regulation: Macrophages in Control, Pharmaceuticals. 11 (2018) 137. https://doi.org/10.3390/ph11040137.

[236] H. Kawabata, R. Yang, T. Hirama, P.T. Vuong, S. Kawano, A.F. Gombart, H.P. Koeffler, Molecular cloning of transferrin receptor 2. A new member of the transferrin receptor-like family, J. Biol. Chem. 274 (1999) 20826-20832. https://doi.org/10.1074/jbc.274.30.20826.

[237] A.P. West, M.J. Bennett, V.M. Sellers, N.C. Andrews, C.A. Enns, P.J. Bjorkman, Comparison of the interactions of transferrin receptor and transferrin receptor 2 with transferrin and the hereditary hemochromatosis protein HFE, J. Biol. Chem. 275 (2000) 38135-38138. https://doi.org/10.1074/jbc.C000664200.

[238] E. Pawelczyk, A.S. Arbab, S. Pandit, E. Hu, J.A. Frank, Expression of transferrin receptor and ferritin following ferumoxides-protamine sulfate labeling of cells: implications for cellular magnetic resonance imaging, NMR Biomed. 19 (2006) 581-592. https://doi.org/10.1002/nbm.1038.

[239] J. Gu, H. Xu, Y. Han, W. Dai, W. Hao, C. Wang, N. Gu, H. Xu, J. Cao, The internalization pathway, metabolic fate and biological effect of superparamagnetic iron oxide nanoparticles in the macrophage-like RAW264.7 cell, Sci China Life Sci. 54 (2011) 793-805. https://doi.org/10.1007/s11427-011-4215-5.

[240] A. Balakumaran, E. Pawelczyk, J. Ren, B. Sworder, A. Chaudhry, M. Sabatino, D. Stroncek, J.A. Frank, P.G. Robey, Superparamagnetic iron oxide nanoparticles labeling of bone marrow 
stromal (mesenchymal) cells does not affect their "stemness," PLoS ONE. 5 (2010) e11462. https://doi.org/10.1371/journal.pone.0011462.

[241] A. Ruiz, L. Gutiérrez, P.R. Cáceres-Vélez, D. Santos, S.B. Chaves, M.L. Fascineli, M.P. Garcia, R.B. Azevedo, M.P. Morales, Biotransformation of magnetic nanoparticles as a function of coating in a rat model, Nanoscale. 7 (2015) 16321-16329. https://doi.org/10.1039/c5nr03780h.

[242] M.C. Hohnholt, M. Geppert, R. Dringen, Treatment with iron oxide nanoparticles induces ferritin synthesis but not oxidative stress in oligodendroglial cells, Acta Biomater. 7 (2011) 3946-3954. https://doi.org/10.1016/j.actbio.2011.06.052.

[243] M. Geppert, M.C. Hohnholt, S. Nürnberger, R. Dringen, Ferritin up-regulation and transient ROS production in cultured brain astrocytes after loading with iron oxide nanoparticles, Acta Biomater. 8 (2012) 3832-3839. https://doi.org/10.1016/j.actbio.2012.06.029.

[244] A. Laskar, M. Ghosh, S.I. Khattak, W. Li, X.-M. Yuan, Degradation of superparamagnetic iron oxide nanoparticle-induced ferritin by lysosomal cathepsins and related immune response, Nanomedicine. 7 (2012) 705-717. https://doi.org/10.2217/nnm.11.148.

[245] L. Lartigue, D. Alloyeau, J. Kolosnjaj-Tabi, Y. Javed, P. Guardia, A. Riedinger, C. Péchoux, T. Pellegrino, C. Wilhelm, F. Gazeau, Biodegradation of iron oxide nanocubes: high-resolution in situ monitoring, ACS Nano. 7 (2013) 3939-3952. https://doi.org/10.1021/nn305719y.

[246] J.M. Rojas, H. Gavilán, V. Del Dedo, E. Lorente-Sorolla, L. Sanz-Ortega, G.B. da Silva, R. Costo, S. Perez-Yagüe, M. Talelli, M. Marciello, M.P. Morales, D.F. Barber, L. Gutiérrez, Time-course assessment of the aggregation and metabolization of magnetic nanoparticles, Acta Biomater. 58 (2017) 181-195. https://doi.org/10.1016/j.actbio.2017.05.047.

[247] M. Marín-Barba, H. Gavilán, L. Gutiérrez, E. Lozano-Velasco, I. Rodríguez-Ramiro, G.N. Wheeler, C.J. Morris, M.P. Morales, A. Ruiz, Unravelling the mechanisms that determine the uptake and metabolism of magnetic single and multicore nanoparticles in a Xenopus laevis model, Nanoscale. 10 (2018) 690-704. https://doi.org/10.1039/c7nr06020c.

[248] D.A. Kedziorek, N. Muja, P. Walczak, J. Ruiz-Cabello, A.A. Gilad, C.C. Jie, J.W.M. Bulte, Gene expression profiling reveals early cellular responses to intracellular magnetic labeling with superparamagnetic iron oxide nanoparticles, Magn Reson Med. 63 (2010) 1031-1043. https://doi.org/10.1002/mrm.22290.

[249] N. Singh, G.J.S. Jenkins, R. Asadi, S.H. Doak, Potential toxicity of superparamagnetic iron oxide nanoparticles (SPION), Nano Reviews. 1 (2010). https://doi.org/10.3402/nano.v1i0.5358.

[250] R. Schäfer, R. Kehlbach, J. Wiskirchen, R. Bantleon, J. Pintaske, B.R. Brehm, A. Gerber, H. Wolburg, C.D. Claussen, H. Northoff, Transferrin receptor upregulation: in vitro labeling of rat mesenchymal stem cells with superparamagnetic iron oxide, Radiology. 244 (2007) 514-523. https://doi.org/10.1148/radiol.2442060599.

[251] H.H. Gustafson, D. Holt-Casper, D.W. Grainger, H. Ghandehari, Nanoparticle uptake: The phagocyte problem, Nano Today. 10 (2015) 487-510. https://doi.org/10.1016/j.nantod.2015.06.006.

[252] M. Wu, L. Gu, Q. Gong, J. Sun, Y. Ma, H. Wu, Y. Wang, G. Guo, X. Li, H. Zhu, Strategies to reduce the intracellular effects of iron oxide nanoparticle degradation, Nanomedicine (Lond). 12 (2017) 555-570. https://doi.org/10.2217/nnm-2016-0328.

[253] M. Mir, N. Ahmed, A. ur Rehman, Recent applications of PLGA based nanostructures in drug delivery, Colloids and Surfaces B: Biointerfaces. 159 (2017) 217-231. https://doi.org/10.1016/j.colsurfb.2017.07.038.

[254] O. Bixner, E. Reimhult, Controlled magnetosomes: Embedding of magnetic nanoparticles into membranes of monodisperse lipid vesicles, Journal of Colloid and Interface Science. 466 (2016) 62-71. https://doi.org/10.1016/j.jcis.2015.11.071.

[255] M.A. Malvindi, V. De Matteis, A. Galeone, V. Brunetti, G.C. Anyfantis, A. Athanassiou, R. Cingolani, P.P. Pompa, Toxicity assessment of silica coated iron oxide nanoparticles and biocompatibility improvement by surface engineering, PLoS ONE. 9 (2014) e85835. https://doi.org/10.1371/journal.pone.0085835. 
[256] M. Tadic, S. Kralj, Y. Lalatonne, L. Motte, Iron oxide nanochains coated with silica: Synthesis, surface effects and magnetic properties, Applied Surface Science. 476 (2019) 641-646. https://doi.org/10.1016/j.apsusc.2019.01.098.

[257] M. Tadic, S. Kralj, L. Kopanja, Synthesis, particle shape characterization, magnetic properties and surface modification of superparamagnetic iron oxide nanochains, Materials Characterization. 148 (2019) 123-133. https://doi.org/10.1016/j.matchar.2018.12.014.

[258] S. Kralj, D. Makovec, Magnetic Assembly of Superparamagnetic Iron Oxide Nanoparticle Clusters into Nanochains and Nanobundles, ACS Nano. 9 (2015) 9700-9707. https://doi.org/10.1021/acsnano.5b02328.

[259] A. Curcio, A. Van de Walle, A. Serrano, S. Preveral, C. Péchoux, D. Pignol, N. Menguy, C. Lefevre, A. Espinosa, C. Wilhelm, Transformation Cycle of Magnetosomes in Human Stem Cells: from Degradation to Biosynthesis of Magnetic Nanoparticles Anew, ACS Nano. 14 (2019) 1406-1417. https://doi.org/10.1021/acsnano.9b08061.

[260] J.L. Kirschvink, A. Kobayashi-Kirschvink, B.J. Woodford, Magnetite biomineralization in the human brain, Proc. Natl. Acad. Sci. U.S.A. 89 (1992) 7683-7687.

[261] S.A. Gilder, M. Wack, L. Kaub, S.C. Roud, N. Petersen, H. Heinsen, P. Hillenbrand, S. Milz, C. Schmitz, Distribution of magnetic remanence carriers in the human brain, Scientific Reports. 8 (2018) 11363. https://doi.org/10.1038/s41598-018-29766-z.

[262] S. Khan, D. Cohen, Using the magnetoencephalogram to noninvasively measure magnetite in the living human brain, Hum Brain Mapp. 40 (2019) 1654-1665. https://doi.org/10.1002/hbm.24477.

[263] J. Dobson, Investigation of age-related variations in biogenic magnetite levels in the human hippocampus, Exp Brain Res. 144 (2002) 122-126. https://doi.org/10.1007/s00221-002-10660.

[264] Q. Pankhurst, D. Hautot, N. Khan, J. Dobson, Increased levels of magnetic iron compounds in Alzheimer's disease, J. Alzheimers Dis. 13 (2008) 49-52.

[265] F. Brem, A.M. Hirt, M. Winklhofer, K. Frei, Y. Yonekawa, H.-G. Wieser, J. Dobson, Magnetic iron compounds in the human brain: a comparison of tumour and hippocampal tissue, J R Soc Interface. 3 (2006) 833-841. https://doi.org/10.1098/rsif.2006.0133.

[266] A. Kobayashi, N. Yamamoto, J. Kirschvink, Studies of inorganic crystals in biological tissue: magnetite in human tumor, J Jpn Soc Powder Powder Metall. 44 (1997) 294-300.

[267] H. Sant'Ovaia, G. Marques, A. Santos, C. Gomes, A. Rocha, Magnetic susceptibility and isothermal remanent magnetization in human tissues: a study case, Biometals. 28 (2015) 951958. https://doi.org/10.1007/s10534-015-9879-z.

[268] R.R. Baker, J.G. Mather, J.H. Kennaugh, Magnetic bones in human sinuses, Nature. 301 (1983) 79-80.

[269] B.A. Maher, I.A.M. Ahmed, V. Karloukovski, D.A. MacLaren, P.G. Foulds, D. Allsop, D.M.A. Mann, R. Torres-Jardón, L. Calderon-Garciduenas, Magnetite pollution nanoparticles in the human brain, Proc. Natl. Acad. Sci. U.S.A. 113 (2016) 10797-10801. https://doi.org/10.1073/pnas.1605941113.

[270] B.A. Maher, Airborne Magnetite- and Iron-Rich Pollution Nanoparticles: Potential Neurotoxicants and Environmental Risk Factors for Neurodegenerative Disease, Including Alzheimer's Disease, J. Alzheimers Dis. (2019). https://doi.org/10.3233/JAD-190204.

[271] G. Jarockyte, E. Daugelaite, M. Stasys, U. Statkute, V. Poderys, T.-C. Tseng, S.-H. Hsu, V. Karabanovas, R. Rotomskis, Accumulation and Toxicity of Superparamagnetic Iron Oxide Nanoparticles in Cells and Experimental Animals, Int J Mol Sci. 17 (2016). https://doi.org/10.3390/ijms17081193.

[272] C. Hoskins, Y. Min, M. Gueorguieva, C. McDougall, A. Volovick, P. Prentice, Z. Wang, A. Melzer, A. Cuschieri, L. Wang, Hybrid gold-iron oxide nanoparticles as a multifunctional platform for biomedical application, J Nanobiotechnology. 10 (2012) 27. https://doi.org/10.1186/14773155-10-27. 
[273] L. Li, B. Xiao, J. Mu, Y. Zhang, C. Zhang, H. Cao, R. Chen, H.K. Patra, B. Yang, S. Feng, Y. Tabata, N.K.H. Slater, J. Tang, Y. Shen, J. Gao, A MnO2 Nanoparticle-Dotted Hydrogel Promotes Spinal Cord Repair via Regulating Reactive Oxygen Species Microenvironment and Synergizing with Mesenchymal Stem Cells, ACS Nano. 13 (2019) 14283-14293. https://doi.org/10.1021/acsnano.9b07598.

[274] B. Xiao, X. Zhou, H. Xu, B. Wu, D. Hu, H. Hu, K. Pu, Z. Zhou, X. Liu, J. Tang, Y. Shen, Integration of Polymerization and Biomineralization as a Strategy to Facilely Synthesize Nanotheranostic Agents, ACS Nano. 12 (2018) 12682-12691. https://doi.org/10.1021/acsnano.8b07584. 